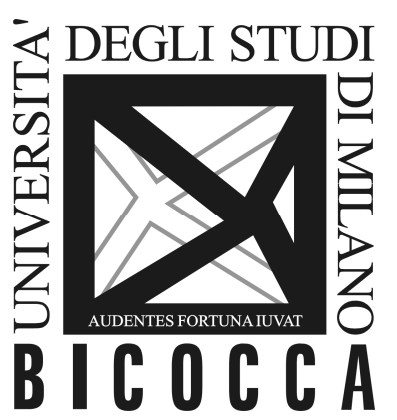

\author{
DEPARTMENT OF ECONOMICS, \\ MANAGEMENT AND STATISTICS \\ UNIVERSITY OF MILAN - BICOCCA
}

DEMS WORKING PAPER SERIES

\title{
Family Size, Sibling Rivalry and Migration: Evidence from Mexico
}

Massimiliano Bratti, Simona Fiore, Mariapia Mendola

No. 358 - January 2017

Dipartimento di Economia, Metodi Quantitativi e Strategie di Impresa Università degli Studi di Milano - Bicocca

http://dems.unimib.it/ 


\title{
Family Size, Sibling Rivalry and Migration: Evidence from Mexico*
}

\author{
Massimiliano Bratti ${ }^{\dagger}$ Simona Fiore Mariapia Mendola $^{\S}$
}

December 21, 2016

\begin{abstract}
This paper examines the causal effects of family size and demographic structure on offspring's international migration. We use rich survey data from Mexico to estimate the impact of sibship size, birth order and sibling composition on teenagers' and young adults' migration outcomes. We find no empirical support for the hypothesis that high fertility drives migration. The positive correlation between sibship size and migration disappears when endogeneity of family size is addressed using biological fertility (miscarriages) and infertility shocks. Yet, the chances to migrate are not equally distributed across children within the family. Older siblings, especially firstborn males, are more likely to migrate, while having more sisters than brothers may increase the chances of migration, particularly among girls. [JEL codes: J13 F22 O15.]
\end{abstract}

Keywords: International Migration, Mexico, Family Size, Birth Order, Sibling Rivalry.

${ }^{*}$ We thank Vincenzo Atella, Catia Batista, Luisa Corrado, Pascaline Dupas, Ivan Etzo, Margherita Fort, Elisabetta Iossa, Marco Mantovani, Luca Nunziata, Rohini Pande, Maria Perrotta, Anna Piil Damm, Pedro Rosa Dias, Nicole Schneeweis, Jenny Simon, Giancarlo Spagnolo, Shqiponja Telhaj, Pedro Vicente, Daniela Vuri, Alan Winters, and seminar audiences at University of Sussex, SITE-Stockholm School of Economics, Nova School of Business and Economics (Lisbon), University of Bologna, University of Turin, University of MilanoBicocca, University of Rome "Tor Vergata," 13th IZA Annual Migration Meeting (Bonn), Royal Economic Society Conference (Brighton), ESPE Conference (Izmir), SIE Conference (Naples) and AIEL Conference (Trento) for useful comments and discussions. The usual disclaimer applies.

†European Commission Joint Research Centre, Università degli Studi di Milano and IZA, massimiliano.bratti@unimi.it

‡Università degli Studi di Bologna, simona.fiore3@unibo.it

${ }^{\S}$ Corresponding author. Università degli Studi di Milano-Bicocca and IZA, mariapia.mendola@unimib.it 


\section{Introduction}

Migration from poor to rich countries is one of the most important ways through which workers can increase their earning potential as well as their families' welfare back home (Chen et al. 2003, Kennan and Walker 2011, Clemens 2011). A key feature of migration is that it mainly involves young adults who are more likely to have a positive net expected return to migration due to their longer remaining life expectancy (Sjaastad 1962). Despite a large literature on the individual determinants of migration decisions, little attention has been paid to the role of the size and the structure of the childhood's household — in particular the role of siblings - on migration investment decisions. This is a significant gap given that migrants come from high-fertility countries and typically leave behind several household members who oftentimes are siblings (Hatton and Williamson 1998, Hanson and McIntosh 2010). This paper adds to the literature by providing novel evidence on the causal effect of the household demographic characteristics on offspring's international migration.

Migration is a human capital investment whose benefits decline with age. According to recent UN figures, worldwide international migrants aged 15 to 24 account for 12.5 per cent of total migrants worldwide, and when migrants between the ages of 25 and 34 are added, young migrants represent over 30 per cent of the total (UNDESA 2011). The proportion of youth migrants is much higher in developing countries and it more than doubles if we consider internal migrants as well (UN 2013).

Since costs and benefits of labor mobility involve both the (young) migrant and her origin family, the literature on the determinants of migration has emphasized the important role of household (along with individual) factors in the migration decision (e.g., Rosenzweig and Stark 1989, Stark 1991). This holds particularly in developing countries, where migration has been shown to be a family strategy to diversify income sources, increase earnings and improve household security through remittances (e.g., Stark and Bloom 1985, Yang 2008, Antman 2012). As a result, family migration strategies may involve the costly parental decision to dispatch one of the children to work in a different city or abroad, and to invest in a potentially remitting child (Lucas and Stark 1985, Jensen and Miller 2011). However, parents face a number of trade-offs when allocating resources across their children, due to either limited household resources or (perceived) different returns to the migration investment 
(e.g., son bias). ${ }^{1}$ This may generate 'resource dilution effects' in large families or competition (rivalry) among siblings from the same household (Garg and Morduch 1998, Black et al. 2005, Jayachandran and Kuziemko 2011). We know surprisingly little about the importance of family size and structure in the determinants of migration decisions.

To the best of our knowledge, this is the first paper to assess the impact of demographic characteristics of one's childhood household, i.e. sibship size, birth order and composition of siblings (by gender and age), on the likelihood to migrate abroad. ${ }^{2}$ We address this question in the context of the Mexico-U.S. mass migration in the 1990s. Mexico is one of the largest migrant-sending and remittance-recipient countries worldwide, with a migration wave that swelled in the 1970s and kept growing in the 1980s and 1990s, ranging from 5.2 percent of Mexico's national population in 1990 to a peak of 10.2 per cent in 2005 (Hanson and McIntosh 2010). According to the Mexico Population Census, during the 1990s alone, 9 percent of Mexicans aged 16 to 25 migrated to the United States. A distinguishing feature of last century Mexico-U.S. migration is that most migrants typically have low levels of education and many of them have their first U.S. jobs in seasonal agriculture (Martin 1993). ${ }^{3}$ According to U.S. Census data, in 199070.4 percent of Mexican immigrant men were high-school dropouts, compared to 12.9 percent of the male native-born working population and 21 percent of non-Mexican immigrant working men (Borjas and Katz 2007). Yet, the American Dream creates opportunities for upward mobility such that Mexican immigrants enjoy income gains with respect to their counterparts living in Mexico, and family members at home share in these gains through remittances (Hanson 2004, Ozden and Schiff 2006, Rosenzweig 2007, Clemens et al. 2010). Importantly, emigration rates differ by age and gender. Using Mexico population censuses Hanson and McIntosh (2010) report that a significant fraction of males start migrating around age 15 with emigration increasing sharply until approximately age 30 and decreasing thereafter, presumably as a result of return migration. By contrast, for females there is less youth migration and migration rates are relatively stable over the course

\footnotetext{
${ }^{1}$ A well-established theoretical literature in economics rationalizes a causal link running from children's economic resources to their lifetime opportunities and adult outcomes (Becker and Tomes 1976, Schultz 1990, Thomas 1990)

${ }^{2}$ Several studies document sibship size and birth order effects in outcomes as varied as schooling, height and IQ (see Pande 2003, Black et al. 2005, Angrist et al. 2010, Jayachandran and Pande 2015, among others).

${ }^{3}$ U.S. policy supported the recruitment of rural Mexicans under bilateral agreements between the $1940 \mathrm{~s}$ and the 1960s (e.g., the Bracero Program) but most of the 20th century Mexican migrants arrived and were employed outside guestworker programs (Martin 1993).
} 
of their lives. ${ }^{4}$

Moreover, the wave of Mexican migration in the 1990s crosses over a demographic boom that petered out years later. Mexico's fertility rate stood at about seven children per mother in 1970. The gradual spread of family planning practices contributed to impelling the fertility transition in the country where, by 2005 , the number of children per woman declined to slightly more than two (Cabrera 1994). ${ }^{5}$ Yet, despite the abundant evidence on the potentially significant implications of high fertility rates for child investments and economic outcomes, the existing literature provides scant rigorous analysis of the link between family size and the international migration of offspring. ${ }^{6}$

By using two waves of a large and nationally-representative demographic household survey, we focus on the determinants of migration of Mexican adolescents and young adults in the age range 15 to 25 . Our large dataset allows us to overcome the limitations of small samples of children, and it includes detailed information on fertility histories, infant and general mortality. Importantly, it allows us to address the potential endogeneity of parental fertility choices which arises from the fact that families who choose to have more (or less) children may also be those who value child out-migration more. We address this endogeneity issue by exploiting exogenous variation in family size induced by biological fertility (miscarriage at first pregnancy) and infertility shocks (Agüero and Marks 2008, Miller 2011). We further investigate birth order, sibling-sex and sibling-age composition effects on migration by estimating family fixed-effects models, in which identification comes from differences across siblings. This is important in order to shed light on the intra-household selection process into migration, which has significant implications for child welfare, gender disparities and the ultimate impact on origin families (Chen 2006, Mourard 2015).

We find no evidence that high fertility drives migration choices at the household level. The positive correlation between fertility and migration disappears when the potential endogeneity of sibship size is addressed. Results are robust to several changes in both the

\footnotetext{
${ }^{4}$ See Figure 2 reported in Hanson and McIntosh (2010).

${ }^{5}$ In 1974 a new population policy was designed in Mexico with the aim of reducing population growth and promoting development. The new institutional structure established to ensure policy implementation (the National Population Council-CONAPO) has expanded geographically and socially over time (Zuniga Herrera 2008).

${ }^{6}$ In what follows we use 'family size', i.e. the number of children, and 'sibship size', i.e. the number of siblings, interchangeably: the former takes the point of view of parents, whereas the latter takes the perspective of children.
} 
estimation sample and the estimation strategy.

On the other hand, the chances to migrate are not equally distributed across children within the family. We find that older siblings, especially firstborn males, are more likely to migrate, while having more sisters than brothers may increase the chances of migration, especially among females. This is so as investing in low parity children lengthens the time period over which the family expect to reap the benefits from having a migrant child and, hence, maximize the net returns. Moreover, a Mexican boy may be more valuable to send as a migrant abroad than a girl. Indeed, labor market returns for Mexican males in the U.S. were relatively high in the 1990s (e.g., in the farm sector) with respect to females, who were expected to take care of chores and family duties at home. ${ }^{7}$ Overall, these results highlight the importance of the migrant's origin family in driving migration decisions and are consistent with a household's optimal migration model, in which mobility is an investment in the human agent but private costs and rewards involve both migrants and non-migrant household members (Sjaastad 1962, Stark 1991).

These findings have relevant implications for policy makers and researchers. First, they rule out a mechanism through which high fertility per se may constitute an important push factor of migration. Many observers have been highlighting the importance of the demographic pressure on migration flows from high-fertility countries to advanced economies (e.g., current migration from Africa and Asia towards Europe). Indeed, by observing a positive association between fertility and migration flows, implications may be drawn that smaller families may lead to lower rates of mobility. Yet, our paper shows that this is not the case. ${ }^{8}$ Second, our analysis can contribute to explaining the impact on migration of fertilityreducing programs — such as investments in family planning, sex and reproductive healthwhich have been endorsed in many developing countries as a policy response to the apparent vicious circle of high-fertility, poverty and economic stagnation (Schultz 2008a, Miller and Babiarz 2014). Some of these programs have been implemented in high fertility societies

\footnotetext{
${ }^{7}$ We study young adults in Mexico in the mid-1990s, where fertility decisions of their mothers were made across the 1970s and 1980s. At that time, the country was classified as a developing poor economy. Moreover, the patriarchal social structure along with the lack of markets or institutions were more likely to be managed by the family - with gender roles - than it is currently the case in Mexico.

${ }^{8}$ Fertility is only one determinant of population growth, along with mortality (life-expectancy) and migration. Our findings suggest that decreasing population growth by reducing fertility does not matter for migration decisions at the household level. Yet, lower population growth may still have an impact on out-migration (e.g., through changes in labor supply), but not through the mechanism of family size.
} 
with significant out-migration rates, such as Mexico, but little is known about the (intended and unintended) consequences of the former on the latter. Third, our empirical findings hint to the fact that parental investment in offspring's migration may matter for fertility decisions in contexts of poor resources and high emigration opportunities. The reason is that, in developing settings, the offspring are the primary caretakers of parents and they may do so by providing support to their origin family through emigration and spatial diversification in residential location. Finally, by showing that not all children in the household have the same chance to migrate, our results point to the existence of an intra-household selection process which may have important implications in terms of individual (child) welfare and income distribution.

The paper unfolds as follows. Section 2 describes the link between household structure and migration as considered by the related literature on human capital investment. Section 3 presents the data and sample selection. The methodology and empirical strategy are described in Section 4. Section 5 presents our main results on sibship size effects on migration while Section 6 reports results on the role of birth-order, gender and sibling composition. Finally, Section 7 summarizes our main findings and concludes.

\section{Related literature}

Standard economic theory conceives labor migration as an investment in human capital whereby relocation requires up-front resources followed by a positive payout which occurs in the future (Sjaastad 1962, Schultz 2008b, Dustmann and Glitz 2011). Positive returns on migration, which are higher for young people, are primarily conceived in terms of both migrants' earnings and remittances sent back home (Stark and Bloom 1985, Yang 2008, Amuedo-Dorantes and Pozo 2011). Indeed, people decide to migrate because they expect their own or their family's payoff to be higher in terms of a different and higher profile of earnings, quality of life, health and security or they do so because migration mitigates the risk of household portfolios at origin (Chen et al. 2003, Kennan and Walker 2011, Clemens 2011). Recent evidence shows that - after controlling for self-selection - workers who move from a poor to a rich country can experience immediate, lasting, and very likely increases in earnings, even for performing exactly the same tasks (Gibson and McKenzie 2012, Ashen- 
felter 2012). ${ }^{9}$ Beyond income gains for migrants, cross-border migration typically brings additional liquidity to the family members left behind through remittances, which significantly support consumption and investment decisions, in addition to the management of risk and credit constraints in the household of origin.

Given the key economic role played by migrants' remittances, especially in developing contexts, several contributions in the migration literature point to the household as the main unit for migration choices (Rosenzweig 1988, Stark 1991, Ghatak and Price 1996). The core feature of this collective decision-making framework is that the family aims at maximizing household income and therefore can make the costly decision to dispatch one (or more) young member to work in foreign labor markets in order to receive remittances (Stark and Bloom 1985). Thus, in the absence of well-functioning credit or insurance markets, migration can be a household investment strategy whereby one or more members are assigned to work in the local economy while others are sent abroad to act as a source of insurance or financial enhancement. Empirical evidence on the implications of migration as a family security strategy in developing countries is abundant (see Ratha et al. 2011, for a review). For instance, Rapoport and Docquier (2006) survey the different motives for remittances sent by migrants, which are also found to be used as a form of support for the elderly (see also Clemens et al. 2015). By using data from Mexico, Antman (2012) shows that children migrated to the U.S. (strategically) provide financial contributions to the health care of their parents (see also Stohr 2015). At the same time though, little evidence exists on the degree to which the family environment - in particular family size and composition - affects children's out-migration decisions.

The link between the household structure and parents' investments in the human capital of their children has received substantive attention in the household economics literature. Theoretical models of fertility choices have been widely influenced by the argument of the 'quantity-quality (QQ) trade-off'. The QQ model treats the quantity and quality of children in a similar fashion as other consumption goods in the household so that, in the absence

\footnotetext{
${ }^{9}$ By combining household data in Mexico with U.S. and Mexico population censuses, and controlling for self-selection on observables and unobservables in migration, recent works estimate that yearly income gains to Mexico-U.S. migration are around 6,700 to 8,000 U.S. dollars (Hanson 2004, Clemens et al. 2010). Moreover, according to the 2009 poll by the Pew Research Center, one third of all Mexicans would move to the U.S. if they could do so, and half of these potential Mexican migrants reports to be prepared to move illegally to the U.S.. According to more than 55 percent of those polled in Mexico, Mexicans who move to the U.S. have a better life despite well-known hardships, whereas less than 15 percent report that life is worse in the U.S.
} 
of parental discrimination between children, there is a trade-off between child 'quality' (or outcomes) and the number of children within a family (Becker 1960, Becker and Lewis 1973, Becker and Tomes 1976). However, in many of today's developing countries (as well as in rich countries around the time of their industrial revolution) parents have often used their children as a substitute for missing institutions and markets, notably social security in old age (e.g., Nugent 1985, Cigno 1993, Ray 1998). ${ }^{10}$ According to this framework - known as the 'old-age security hypothesis' - on top of the consumption-good aspect of children, fertility choices are influenced by the child role of investment-good or household asset. Children embody income-earning possibilities for both themselves and their parents, which may be the reason why, in poor contexts (i.e. with weak formal markets and social safety-nets) people generally choose to invest in their future in the form of children (Duflo and Banerjee 2011). At the same time, the traditional system of family arrangement may have important consequences on economic choices and offspring's outcomes (Platteau 1991, Jayachandran and Pande 2015).

Although an extensive empirical literature provides evidence on the role of household size and composition in parental investments in other forms of children's human capital, such as education and health (e.g., Garg and Morduch 1998, Black et al. 2005, Jayachandran and Pande 2015), demographic characteristics of families (e.g., sibship size, birth-order and sibling composition) have been less analyzed in the context of migration decisions. ${ }^{11}$ Yet, if migration is costly and migrants move at a relatively young age, it is plausibly the result of family decision-making in which parents decide on their children's relocation (potentially retaining some control over their children's incomes as well), or that children are influenced by their family background (e.g., household characteristics, number of siblings) when deciding whether to move abroad. Thus, in families with limited resources and more than one child to raise, greater sibship size may negatively affect child out-migration through a 'resource dilution effect' (i.e. a smaller share of resources per child) or because more family-work

\footnotetext{
${ }^{10}$ Recent contributions on contemporary developed societies show that when pensions and income from retirement decrease, the old-age security motive matters for fertility decisions even in these settings (see Gábos and Kézdi 2009, Billari and Galasso 2014).

${ }^{11}$ Findings on the impact of family size on child outcomes are mixed. Early results tended to predominantly show that children from larger families have worse outcomes, especially in terms of human capital investment and earnings (Rosenzweig and Wolpin 1980, Hanushek 1992, Parish and Willis 1993). However, after controlling for the endogeneity of fertility, in more recent papers family size does not turn out to adversely affect child outcomes (see Black et al. 2005, Angrist et al. 2010, Fitzsimons and Malde 2014, among others).
} 
is needed at home, e.g., care for younger children (Becker and Lewis 1973, Giles and Mu 2007). On the other hand, larger families may increase the pressure of the family hierarchy, the number of income earners and the amount of disposable resources to support family members. Hence, a reallocation of resources from children to parents may become necessary so that young household members are dispatched abroad in order to send remittances or offer potential support back home. In particular, if children contribute to family welfare either through child-labor, economic diversification or parental-care, then a larger number of siblings may have a positive effect on the out-migration of one (or more) of them (Brezis and Ferreira 2016). The relative strength of these competing effects of family size is ultimately an empirical matter.

A related question is how birth-order and sibling sex/gender composition affect the likelihood of migration within the household. In the absence of any explicit strategic motive or intrinsic preference on the part of parents, all children (e.g. earlier/later parities, boys/girls) may have the same chance to migrate. However, if migration is placed in a household resource allocation framework, being an early vs. a late parity, a boy vs. a girl, having younger vs. older siblings may entail different marginal utilities from such an investment choice. This is so as the benefits of migration (and perhaps some of the costs) accrue over a delimited period of time and may depend on a child's own characteristics as well as those of his/her siblings.

While to our knowledge we are the first to systematically look at this question in the context of migration, several previous works have empirically investigated the role of birth order and sibling composition (by age and gender) on household investment in children's human capital (Black et al. 2005, Jayachandran and Kuziemko 2011, De Haan and Rosero 2014). In general, findings are consistent with the argument that poor households invest more in children whose economic returns are higher. On the other hand, there are contexts where social norms and culture play a significant (possibly additional) role in biasing household decisions towards specific children - typically boys as in patriarchal societies (Jayachandran and Pande 2015). In addition, in contexts of limited resources and high returns to human capital investment, siblings may become rivals and some children (typically girls) turn out to have lower economic opportunities than their siblings. Even with compelling evidence, disentangling alternative hypotheses underlying parental decisions on child investment is a 
challenging exercise (especially when they are observationally equivalent) and is beyond the scope of this paper. However, unlike other forms of human capital, migration from low- to high-income regions is a one-time costly decision whereby typically no more than one or two household members are enabled to leave. From this perspective, we expect migration choices within the household to be primarily driven by economic considerations, i.e. the maximization of the present value of the return to child migration. Hence, in our empirical analysis, by exploiting the interplay between the effects of birth-order, gender, and sibling composition, we test different models and allow for a better separation between alternative mechanisms through which the sibling structure may affect child migration outcomes.

\section{Data and sample selection}

This study uses data from the 1992 and 1997 waves of the Encuesta Nacional de la Dinámica Demográfica (ENADID), a cross-section survey conducted by the National Institute of Statistics and Geography (INEGI) in Mexico. Each ENADID's wave surveys more than 50,000 households from all over the country and is representative of the Mexican population. The dataset is very rich and unique, collecting comprehensive information on women's fertility as well as migration history of all household members, in addition to standard socio-economic characteristics. Importantly, by using detailed demographic information on age (month and year of birth) and gender of individuals in the same household with the same mother, we are able to identify all biological families in the sample and recover complete information on the number and gender of all siblings (also those not currently living in the household of origin).

The ENADID collects detailed information on fertility for all women aged 15 to 54 at the time of the survey. Women answer specific questions on the number of children ever born, their gender and birth order, current and past contraceptive use, fertility preferences, and their socio-economic and marital status. Such information allows us to precisely construct our key explanatory variable, namely sibship size, which is the total number of biological siblings of individuals in the sample. Moreover, it enables us to identify parental exogenous shocks to fertility induced by infertility episodes and miscarriage at first pregnancy (see Section 4.2 for more details). In line with the medical definition of infertility ${ }^{12}$ and with

\footnotetext{
${ }^{12}$ The medical literature defines infertility as the failure to conceive after a year of regular intercourse without
} 
the extant literature, we restrict our sample to children of non-sterilized women who are not currently using contraception (including natural methods) or who never did. In so doing, we identify women with infertility episodes as those who report not to use contraception because of infertility problems (see Agüero and Marks 2011). Indeed, women realize they have infertility problems only if they do not use contraception. Moreover, it is especially for this group that infertility affects total fertility (instrument's strength). This sample selection does not significantly reduce our sample since from ENADID Mexican women not using contraception are 80 percent of the population.

The ENADID allows us to define household members' international migration experience based on three separate questions: (i) whether there is any household member (even temporarily absent) who migrated abroad during the five years prior to the survey; (ii) whether any household member has ever worked in or looked for work in the United States (and the year in which this occurred); and (iii) whether the respondent reports a period of residence abroad at any point in time prior to the survey. The use of these three different sources of information for migration episodes ensures that we are able to capture a relevant part of the international migration phenomenon. ${ }^{13}$ Overall, in 1997 (1992) almost 18 (15) percent of households in Mexico reports having a member who migrated abroad.

Since we are interested in the effect of family size on parental investment in offspring's migration, we define individual migration episodes as non-tied migration, i.e. we exclude from the sample children who experienced episodes of tied-migration joint with their parents and those whose parents have an international migration experience. We do so for two main reasons. First, family and individual migration are inherently two very different choices and our focus is on the latter. Second, we exclude parents with migration experiences because parental absence due to migration may affect fertility and hence generate a reverse causality problem. $^{14}$

Figure 1 reports the incidence of non-tied migration by age and gender in Mexico showing that, overall, migrants are massively concentrated (more than 70\%) in the age range of 15 to 25 . Hence, throughout our analysis we restrict the sample to individuals aged 15 to

\footnotetext{
contraception.

${ }^{13}$ Other papers on migration using the same data set are Hanson (2004) and Mckenzie and Rapoport (2007) among others.

${ }^{14}$ We check the robustness of our findings to the inclusion of tied-migrants (about 10 percent of the sample), including parents' migration status among the controls, and results are unaffected (available upon request).
} 
25. This is also consistent with the argument that Mexican youngsters finish compulsory schooling and can potentially enter the labor market at the age of 15 , whereas beyond the age of 25 they are more likely to make their own lives apart from the origin family.

[Figure 1 about here]

One limitation of the data is that, by asking migration information only for children who are still considered household members, the ENADID may introduce a potential sample selection bias if the children we observe are more or less likely to come from larger families due to long-term (more than five years) migration episodes. ${ }^{15}$ We address this concern in a number of ways. First, by focusing on migration outcomes in the age range 15-25, we lessen concerns of household partitioning. In fact, the average age at first marriage in Mexico during the 90s was between 22 and 23 for females and about 25 for males. ${ }^{16}$ Thus, we expect the majority of non-household (missing) children in our sample to be mostly married young daughters. Moreover, Mexico-US migration during the 90s was mostly temporary in nature with an average duration of about 2 years. ${ }^{17}$ Yet, if the probability of being observed in the data is correlated with family size, the estimated effect of family size on migration may still be biased. In Appendix A, we run a series of robustness checks - which include sensitivity analyses on subsamples of men and younger children along with a direct check of sample bias - in order to show that our results do not suffer from such a sample selection bias.

Our final estimation sample includes 26,743 children in the age range of 15 to 25 , whose mothers are on average 45 years of age. The average birth spacing between the first and the last child is 13 years, which is below the minimum age of the individuals we consider (15). The latter ensures that, on average, our measure of fertility can be interpreted as completed fertility at the moment of the young adult's migration. ${ }^{18}$

In our sample of individuals, 5.2 percent are migrants, with male and female migration rates of 7.07 and 2.92 percent, respectively. In Figure 2 we plot the average migration rate

\footnotetext{
${ }^{15}$ It is worth recalling that ENADID collects information on migration episodes also for temporarily absent household members, as long as migration occurred in the five years before the survey. Thus, ENADID only lacks information on permanent or long-term migration for non-household members.

${ }^{16}$ World Bank Gender Statistics, http://databank.worldbank.org.

${ }^{17}$ Computed on migrants of all ages.

${ }^{18}$ Our sample of children does not include those with mothers older than 54 years of age (9 percent of the total population aged 15-25) since fertility information was not collected from them.
} 
of the boys and girls in our sample by sibship size. A positive association between sibship size and migration for sons clearly emerges. Individual sample characteristics are reported in Table 1 according to migration status. Migrants are mostly males (75 percent) and they report significantly more brothers and sisters than non-migrants. Moreover, migrant children appear to be slightly older and live in less educated but wealthier households than nonmigrant children.

[Figure 2 about here]

[Table 1 about here]

\section{Empirical strategy and identification}

\subsection{Sibship size and birth order effects}

We are interested in the effects of sibship size and composition on an individual's likelihood to migrate. In order to estimate the effect of sibship size, though, we need to control for the birth order of children (see, for instance Black et al. 2005). Indeed, if parents have a preference for the first children they have (i.e. lower parities), and invest comparatively more resources in them, then a spurious negative correlation between sibship size and human capital investments may emerge simply because in larger families we also find children with higher birth orders. In other words, the two variables of birth order and sibship size are highly correlated. In particular, although one can assess the effect of family size on firstborns by looking at firstborns' outcomes in families of different size, it is not possible to examine, for instance, the outcome of a fourth-born child when sibship size changes from two to three, given that fourth born children are only found in larger families.

Recently, Bagger et al. (2013) have proposed a theoretically-grounded methodology to disentangle the two effects. We draw on their idea to employ a similar two-step estimation strategy. In a first step we estimate the following regression using OLS:

$$
M_{i j}=\alpha_{0}+\sum_{k=2}^{K} \alpha_{1 k} b o_{i j k}+\alpha_{2} \mathbf{X}_{i j}+u_{j}+\varepsilon_{i j}
$$

where the outcome variable $M_{i j}$ pertains to the migration status of child $i$ in household $j$ and 
is a dichotomous indicator of either current or past migration experiences abroad. $b o_{i j k}$ is a dichotomous indicator for the child being of birth order $k=2, . . K$ where $K$ is the maximum birth order of children in our sample and $k=1$ (i.e. firstborn) is the reference group; $\mathbf{X}_{i j}$ is a vector of individual covariates including child gender, age, age squared and cohort indicators (one for each year of birth). ${ }^{19} u_{j}$ is a family fixed effect, and $\varepsilon_{i j}$ an idiosyncratic error.

The effect of sibship size is captured in equation (1) by the family fixed effects, which control for any (observed and unobserved) difference between families. The birth order fixed effects capture the differences in the probability of migration between children of different orders within the same family. Systematic differences in ages between different parities, which are likely to affect mobility choices, are controlled for by a quadratic in child age. Only within-family variation is exploited in these estimates, and the birth order effects are not contaminated by between-family variation in family sizes, i.e. the fact that children in larger families also have higher average birth orders.

In the second step, we subtract the birth order effects from the dependent variable, i.e. we compute the difference $\widehat{N M}_{i j}=M_{i j}-\sum_{k=1}^{K} \hat{\alpha}_{1 k} b o_{i j k}$ where $N M$ stands for 'netted migration,' and use it as the dependent variable in the second step. ${ }^{20}$ Hence, the following equation is estimated:

$$
\widehat{N M}_{i j}=\beta_{0}+\beta_{1} S_{i j}+\beta_{2} \mathbf{X}_{i j}+\beta_{3} \mathbf{W}_{j}+v_{i j}
$$

where $S_{i j}$ is sibship size. The coefficient $\beta_{1}$ captures the effect on migration of being raised in a family with sibship size $S_{i j}$ for the 'average child' in that family, i.e. regardless of his/her birth order. $\mathbf{X}_{i j}$ is a vector of individual covariates defined as above and $\mathbf{W}_{j}$ includes family background characteristics such as the mother's and father's age and age squared, and the mother's and father's years of completed education. In some specifications, we also control for maternal health (chronic diseases), father's absence from the household (i.e. widowed and divorced single-mother families) and municipality fixed effects. The latter capture the rural vs. urban residence along with many other factors related to different local cultural or socio-economic conditions such as access to contraception, water sanitation, quality of

\footnotetext{
${ }^{19}$ We can include a control for both age and birth cohort indicators because we use two cross-section surveys.

${ }^{20}$ Coefficients of all birth order indicators (including firstborns) are recovered using the method described in Suits (1984), whereby the coefficients on the dummy variables show the extent to which behavior of each birth order deviates from the average behavior (of all birth orders).
} 
health care, etc. Since the dependent variable has been generated by a regression, standard errors are corrected by weighting the estimation with the inverse of the standard error of $\widehat{N M}_{i j}{ }^{21}$ We estimate equation (2) by using either Weighted Least Squares (WLS) or Twostage Least Squares (2SLS) (see the next Section.) Throughout, standard errors are clustered at the household level so as to account for potential error correlation across siblings.

\subsection{The sibship size effect: Identification strategy}

If the number of children and investment in child out-migration are both outcomes over which parents exercise some choice, then the OLS estimate of the sibship size effect in equation (2) would provide spurious evidence. In other words, parental fertility may be endogenous with respect to children's migration. It is plausible, for instance, that the opportunity to send some children abroad modifies parents' fertility choices. In developing countries, children are a valuable asset for parents and a source of old-age support. If offspring's migration opportunities are not equally distributed across families, it may be the case that households with lower migration costs or higher benefits for their members will also decide to have more children. Alternatively, unobservable parental preferences for children and old-age support through migration may positively co-vary. Stark (1981) and Williamson (1990), for instance, postulate that heterogeneity in parental preferences for childbearing and for migration are systematically related, and in a context such as Mexico where migration cum remittances is an essential lifeline to households of origin, they are generally positively related. In both of these cases, the positive association observed between fertility and child out-migration is likely to overstate the true causal relationship. This pattern of heterogeneity of preferences or migration costs may lead to a larger positive association between fertility and child out-migration than what would be observed if fertility changes were only due to exogenous shocks.

Hence, to clearly identify the relationship between sibship size and migration, an exogenous source of variation in family size is required. The ENADID allows us to identify self-reported infertility from specific questions posed to non-sterilized women who have never used contraceptive methods or who are not currently using them. More specifically,

\footnotetext{
${ }^{21}$ See, for instance, Lewis and Linzer (2005). We also run estimates using White robust standard errors and the results of the analysis are unaffected.
} 
we construct an indicator variable for infertility shocks that takes the value of one if a woman declares she never used contraception or she has stopped using the previous method because of infertility episodes ('infertility shock') and zero otherwise (Agüero and Marks 2008). ${ }^{22}$ The ENADID also enables us to build a second indicator variable that equals one if a woman experienced a miscarriage at first pregnancy ('fertility shock') and zero otherwise. For our identification strategy to be valid, the two instruments must satisfy three conditions - i.e. exogeneity, relevance and the exclusion restriction assumption - that are discussed below.

Infertility or subfertility conditions have already been used in the economic literature to estimate the effect of the number of children and fertility timing on mothers' labor market outcomes (see, for instance, Agüero and Marks 2008, Schultz 2008a, Agüero and Marks 2011). There is evidence that infertility is largely independent of the background characteristics of infertile women. For example, variables such as the father's social status and parity have been shown to be unrelated to observed heterogeneity in fertility (Joffe and Barnes 2000). In an article summarizing the epidemiological literature regarding the role of lifestyle factors (cigarette smoking, alcohol and caffeine consumption, exercise, BMI, and drug use) in female infertility, Buck et al. (1997) conclude that few risk factors have been assessed or identified for secondary infertility. In addition, using U.S. data, education, occupation, and race have been shown to be unrelated to impaired fecundity (Wilcox and Mosher 1993). Importantly, by using data on a large set of developing countries, Agüero and Marks (2011) present evidence that infertility is generally uncorrelated with the background characteristics of women, with a few exceptions such as women's education and rural residence (which will be controlled for in our models).

Also miscarriages and stillbirths have been used to identify fertility tempo and quantum effects on women's labor market outcomes, mainly in advanced countries (Hotz et al. 2005, Miller 2011, Bratti and Cavalli 2014). Miscarriages or spontaneous abortions typically refer to any loss of pregnancy that occurs before the 20th week of pregnancy. By nature, miscarriages should have a negative effect on total fertility, and in our context on sibship size. ${ }^{23}$ Their exogeneity is generally supported by the medical literature. For example, a few pa-

\footnotetext{
${ }^{22}$ Such shocks may be only temporary or have emerged relatively recently. This means that even subfertile women may have large families. The data do not provide information on the age when these problems first arose.

${ }^{23}$ Casterline (1989) stresses that in most societies pregnancy losses produce a reduction of fertility of 5-10\% from the levels expected in the absence of miscarriages and stillbirths.
} 
pers using administrative data, in which rich labor market and health data are merged, show that miscarrying is not generally significantly associated with worse labor market outcomes (e.g., work absences) before miscarriage (Karimi 2014, Markussen and Strøm 2015). Only two etiological factors for miscarriage are recognized by different authors in the obstetrics literature, i.e. uterine malformations and the presence of balanced chromosomal rearrangements in parents (Plouffe et al. 1992). The latter though, are unlikely to be correlated with women's attitudes towards offspring's migration. The number of miscarriages and stillbirths generally increases with the number of pregnancies, which depends in turn on desired fertility, and this could potentially generate a spurious positive correlation between the number of miscarriages and observed fertility. For this reason, we consider only miscarriages that occurred at the first pregnancy (Miller 2011). There is a potential issue of measurement error with this instrument, since women may be unaware of miscarriages or, especially the case with older women, may fail to recall them. Misreporting may affect the strength of the instrument, but we do not expect any specific pattern of correlation between it and parents' attitudes towards child out-migration conditional on the observables (including a quadratic in maternal age). Finally, as it was formulated in the ENADID, the question does not distinguish between voluntary and involuntary abortions. Thus, some of the reported abortions may be actually voluntary, even though induced abortion was illegal and Mexico had the strictest anti-abortion legislation in Latin America during the period under consideration. ${ }^{24}$

For our instruments to be valid, in addition to exogeneity, they have to satisfy the exclusion restriction assumption, i.e. fertility and infertility shocks must have an impact on children's migration only through sibship size. For this reason, in the child migration equation we control for many variables that may act as a confounding factor and for those that may be affected by the shocks while having a direct effect on children's migration. Among

\footnotetext{
${ }^{24}$ For women who voluntary have an abortion, the instrument would be endogenous. However, there is no evident sign in our data that a relevant share of the recorded abortions could be voluntary. For instance, Catholic women in our sample do not tend to abort significantly less than other women (this check can be made only for the 1997 wave, which includes information on religion): for the first group the incidence of abortion is 4.6 percent and for the second group is 4.8 percent. In case the instrument is substantially contaminated by voluntary abortions, we would expect IV estimates to be biased in the same direction as OLS. Indeed, omitting subscripts and in the models without controls, if we define as $M=\beta_{0}+\beta_{1} S+v$ the migration equation, where $M$ and $S$ are child migration status and sibship size, respectively, and $S=\gamma_{0}+\gamma_{1} Z+u$ the sibship size equation (the first stage) and $Z$ the instrument (abortion), $\beta_{1, O L S}=\beta_{1}+\operatorname{Cov}(S, v) / \operatorname{Var}(S)$ while $\beta_{1, I V}=$ $\beta_{1}+\operatorname{Cov}(Z, v) / \operatorname{Cov}(Z, S)$, where $\operatorname{Cov}(Z, S)<0$ and $\operatorname{sign}(\operatorname{Cov}(S, v))=-\operatorname{sign}(\operatorname{Cov}(Z, v))$. In case, for instance, unobserved mother's total desired fertility is positively correlated with children's migration and a substantial share of abortions are voluntary, both OLS and IV will be similarly upward biased.
} 
these variables, we include the mother's age, age at first pregnancy, education, chronic illness/disability, marital status and the husband's characteristics (age, education and absence). In particular, while parental education may directly influence fertility, it also acts as a predetermined proxy for household well-being and poverty. Yet, in a set of robustness checks we include additional controls, namely municipality by year (1992 or 1997) fixed effects, municipality by parental education fixed effects and a household wealth index (see Appendix B).

Table 2 reports the incidence of infertility and miscarriage shocks in our (individual and household-level) estimation samples. Data clearly show a monotonic negative association between infertility and sibship size. For instance, while 13.4 percent and 11.4 percent of women with family sizes equal to one or two, respectively, have experienced an infertility condition, the incidence falls to 3.5 percent for women with seven children or more. A negative relationship also emerges between miscarriage and sibship size, although it is nonmonotonic. In Figures 3 and 4 we report a preliminary visual representation of the relevance of our instruments (more compelling evidence is provided by the first-stage of the 2SLS reported in Section 5). In particular, we use ENADID data to plot the average number of live births by women's age and infertility shock or miscarriage status. ${ }^{25}$ Figure 3 shows that women who ever experienced an infertility condition generally have a lower number of children, and those differences in fertility tend to increase with age. Similarly, Figure 4 displays a negative association between miscarriage at first pregnancy and the total number of live births. Both figures suggest that our instruments are relevant. They also suggest that, although the shocks we consider have a negative impact on family size, overall Mexican women were able to achieve a generally high fertility rate by the end of their fecund life span. This is due to the fact that exogenous infertility shocks, as defined in this and related papers, clearly affect the number of children a woman can have but they may also be temporary in nature (i.e. secondary infertility).

The ENADID provides information on other potential instruments for fertility that have been used in the literature, namely twin births (e.g., Rosenzweig and Wolpin 1980, Angrist and Evans 1998, Càceres-Delpiano 2006) and sibling-sex composition (e.g., Angrist and Evans 1998, Fitzsimons and Malde 2014). Those instruments, however, are not suitable ei-

\footnotetext{
${ }^{25}$ Older women belong to earlier birth cohorts, whose fertility is likely to be higher.
} 
ther for our data or for the Mexican context. Twin births cannot be used in our case because we do not have administrative data, and although we make use of a large survey, we observe twin births only in 1.3 percent of families in our estimation sample. Sibling-gender composition is not suitable to the Mexican context because, for its very nature, it is likely to affect fertility of parents who desire a small number of children. The idea behind the instrument is indeed that parents have an extra child just because they are not happy with the gender of those they already have (i.e. the group of compliers). This typically happens in Mexico when early parities are all females because parents have a son bias (Fitzsimons and Malde 2014). However, average family size in Mexico is very large in our estimation period, the probability of having at least one son is also high, hence the instrument is unlikely to be relevant for a large share of the population. Moreover, in Section 6, we will show that sibling-sex composition has a direct effect on individual migration over and above the number of siblings, clearly violating the exclusion restriction assumption.

[Table 2 about here]

[Figure 3 and 4 about here]

\section{Results on family size}

\subsection{First-step estimation of birth order effects}

We start by estimating the impact of birth order on individual migration, as specified in equation (1), controlling for family fixed effects. The within-family estimator sweeps out all parental- and family-level heterogeneity, including sibship size. Moreover, family fixed effects account for omitted family-specific unobservable factors simultaneously affecting fertility and child migration. The first column of Table 3 reports estimates with a linear specification of birth order on the full sample, whereas in column (2) we allow for a more flexible specification by adding birth-order-specific dichotomous indicators. Regressions control for individual age and gender plus child's birth cohort dummies (one for each year of birth). ${ }^{26}$ Indeed, child age is correlated with birth order and it is also likely to have a

\footnotetext{
${ }^{26} \mathrm{By}$ including child age and cohort dummies, with household fixed effects we are also de facto controlling for birth spacing between siblings.
} 
(non-linear) relationship with migration (which is why we include the age quadratic term).

First, in column (1) we observe that, after controlling for family fixed effects, birth order and individual characteristics, females are significantly less likely to migrate than males by 3.6 percentage points (p.p.). Moreover, the birth order point estimate is negative and statistically significant. Column (2) shows that the effect is non-linear and starts to be economically significant from children of birth order 3 , who are 2.1 p.p. less likely to migrate than firstborns. Although this appears to be a small effect in absolute value, it represents an approximately 40 percent decrease in migration at the sample average (5.2 percent migration rate). The coefficients for the following birth orders are larger in absolute value and peak for birth orders 9 and 10 or more (-16.6 and -20 p.p. respectively).

[Table 3 about here]

\subsection{Sibship size effect: WLS and 2SLS results at the individual-level}

By applying the two-step procedure described above, we turn to the estimation of the sibship size effects. We report the WLS estimates as a benchmark model, where the dependent variable is 'netted migration' (see Section 4.1). ${ }^{27}$ The number of siblings is tallied as the number of currently living biological brothers and sisters of each child. ${ }^{28}$ The first column of Table 4 reports WLS results for a linear specification including sibship size. The highly significant coefficient implies that, on average and after controlling for birth order effects in the first step, adding one sibling is associated with a 1.1 p.p. higher likelihood of migrating for young adults (+17 percent at the sample mean). The same effect holds once we include individual level controls, namely child gender, age, age squared and years of birth indicators (column 2). In column (3) we estimate the same model as above by allowing for differential effects by child gender. The significant negative coefficient for the interaction term indicates that females' likelihood to migrate increase less due to sibship size than for males. Specifically, one extra sibling raises the migration probability more for sons than for

\footnotetext{
${ }^{27}$ The inverse of the standard errors of 'netted migration' are used as weights.

${ }^{28}$ Those currently deceased are excluded from our definition of siblings. This is so because of two reasons: (i) 70 percent of deceased children in our sample died before the first year of life, 90 per cent of them before the second one; (ii) the focus of our analysis is not on young children so that we need to take into account siblings who actually 'had enough time' to both receive and compete over household resources, so that can exclude infant deaths. In Appendix C, we report robustness checks related to concerns about the endogeneity of our definition of sibship size and birth order and estimate models based on ever-born children, i.e. currently alive or deceased.
} 
daughters by 0.8 p.p. In columns (4) to (7), we run the same regressions above while adding further parental, household and geographical-level controls in order to account for potential confounding factors of the relationship between family size and offspring's migration. Specifically, in column (4) and (5) we include parental covariates, which may predict completed fertility and affect child migration, namely mother's years of birth indicators, age at first pregnancy, chronic illness, single status (i.e. widow, divorced, single de facto), father's decade of birth indicators, mothers' and father's (quadratic) age and years of schooling. ${ }^{29}$ In column (6) and (7) we further add municipality fixed effects that, conditional on family size, control for rural/urban residence along with many other local factors related to different cultural or economic conditions, which may have an effect on fertility and migration (e.g., employment rates, migration intensity, access to contraception, social services etc). Overall, the sibiship size effect is essentially unchanged when we control for all of the aforementioned factors, and the same holds for the differential effect by gender.

[Table 4 about here]

Yet, as noted in the methodological section, the coefficients on sibship size reported in Table 4 are still likely to be biased, even when a rich set of demographic and economic controls is included. This is so as fertility may be endogenous with respect to child outmigration. Thus we employ an IV approach and exploit the arguably exogenous fertility variation generated by episodes of infertility and miscarriage. Since these events can vary the actual family size from the desired one, we use infertility shocks and miscarriage at first pregnancy to identify the effect of sibship size on child out-migration. In Table 5 we present two-stage least squares (2SLS) estimates using a linear version of our 'saturated' specification (with all controls) and the two-step methodology, as outlined above, to estimate equation (2). In column (1) we instrument sibship size with an indicator variable for infertility shocks taking value one if the woman declares she never used or she stopped using contraception because of infertility. In column (2), instead, we report results using a woman's experience of miscarriage on her first pregnancy as an instrument. Eventually, in column (3) we present

\footnotetext{
${ }^{29} \mathrm{We}$ are de facto also controlling for mother's age at delivery, which is a linear combination of child's age and mother's age. As far as parental controls are concerned, we have more missing information for fathers than it is the case for mothers. As to keep the sample size constant, we further include a dummy variable for missing information of fathers.
} 
results using both instruments in an overidentified model. Throughout all models, the first stage results point to a strong and highly significant relationship between infertility/fertility shocks and completed fertility. In particular, children whose mothers experienced an infertility shock have a reduction in their sibship size of nearly $0.5(t=-5.2)$ with an $F$-statistic of 26.9 (column 1). The negative impact of miscarriage on sibship size is similar in magnitude (-0.437) with an $F$-statistic of 19.13 (column 2). Also the $F$-statistic of the joint significance of the instruments in the over-identified model is as high as 23.37 (column 3). The sibship size effects estimated using 2SLS are always small and statistically insignificant at standard confidence levels. For all models, the Anderson-Rubin $F$-statistic cannot reject that the coefficient on the instrument is zero in the reduced form, and the Hansen $J$-statistic confirms the validity of the instruments in the overidentified model. ${ }^{30}$ Even though in all specifications we control for parental education, in Appendix B we show that our results are robust to the inclusion of a number of additional controls for household economic conditions, namely municipality by time fixed effects, municipality by parent's education fixed effects and a household wealth index.

[Table 5 about here]

In Table 6 we report results of the same 2SLS regressions as above while testing the sibship size differential effect by gender in the pooled sample with interaction terms. ${ }^{31}$ Results do not point to any significant difference in the impact of sibiship size between boys and girls, as it turns out to be insignificant for both (columns 1-3). When using miscarriage as an instrument, though, we cannot draw strong conclusions as the $F$-statistic for the interacted endogenous variable is rather low (4.27, column 2). However, even in this case the Anderson-Rubin $F$-statistic confirms that we cannot reject the hypotheses of sibship size not affecting child migration.

[Table 6 about here]

\footnotetext{
${ }^{30}$ Interestingly, the point estimate of the effect of sibship size on child migration obtained with the abortion instrument (which might include voluntary abortions) is lower than the one obtained with the infertility instrument, which we consider to be less affected by endogeneity issues, and much lower than the OLS estimate, a fact that is inconsistent with the premise that induced abortions include a substantial share of total abortions (cf. footnote 24).

${ }^{31}$ The interaction effect sibship size $\times$ female is instrumented using the interaction instrument $\times$ female, where the instrument is infertility or miscarriage depending on the specification.
} 
Overall, findings in this section point to the negligible role of family size on children's migration outcomes. This evidence is not in line with the popular view that high fertility in developing countries is a major cause of international emigration: according to our estimates this correlation is driven by unobservable variables which make some families more prone to both have more children and send some of them abroad.

\subsection{Robustness check: Household-level estimates}

In this section, we estimate the migration equation while using the household instead of the individual as the unit of analysis. ${ }^{32}$ In so doing we are able to check the robustness of our baseline family size effect to changing the estimation sample and strategy. Indeed, the twostep procedure reported above is based on household fixed effects and therefore can only be applied to households with more than one child in the full sample. By contrast, while focusing on the total number of migrants in the household as a function of total fertility, we do not need to control for birth order effects and we can use a standard IV procedure. As a consequence, household-level regressions allow us to include also one-child families in the sample. ${ }^{33}$ Thus, we estimate a specification as follows:

$$
m_{j}=\gamma_{0}+\gamma_{1} n_{j}+\gamma_{2} \mathbf{W}_{j}+v_{j}
$$

where the dependent variable is the number of children in the age range 15-25 who ever migrated in household $j$ and the independent variable of interest is $n_{j}$, i.e. the total number of children in household $j$. The coefficient $\gamma_{1}$ captures the increase in the number of migrants associated with a unitary increase in family size. Like in the child-level estimates, $\mathbf{W}_{j}$ includes family background characteristics such as the mother's and the father's age, age squared, and years of completed education, mother's age at first pregnancy, an indicator for the father not being in the household and municipality fixed effects; $v_{j}$ is an household-level error term. This specification is estimated both with OLS and with 2SLS.

[Table 7 about here]

\footnotetext{
${ }^{32}$ More precisely, our unit of analysis is the biological family.

${ }^{33}$ Thus, in these estimates we also exploit individuals who do not have siblings, and look at whether they are more (less) likely to migrate than individuals with siblings.
} 
Results are reported in Table 7. Column (1) shows that a unit increase in the number of children is associated with an average increase in the number of migrants of $0.02(t=12.3)$. Column (2) reports the 2SLS estimate using the infertility instrument. The first stage shows a reduction of $-0.753(t=-12.1)$ in the total number of children per woman who experienced an infertility shock, with an $F$-statistic of 145.4. The first-stage coefficient is a bit higher in magnitude than the one obtained in the child-level estimates (-0.5), probably because of the inclusion of one-child households in the estimation. Indeed, women with only one child are those who may have suffered from more severe sub-fertility conditions and for whom the instrument is likely to be stronger (see Table 2 above). In spite of the strength of the instrument, the second stage does not show any evidence of a positive effect of fertility on migration: the coefficient on the number of children turns out to be negative and statistically insignificant. Column (3) reports the IV results using the variation in the number of children generated by miscarriage. Also in this case the first-stage coefficient is highly statistically significant and negative, with an $F$-statistic of about 45 . The negative impact of miscarriage on total fertility is smaller than the one exerted by infertility, yet it is quite large and precisely estimated, i.e. $-0.476(t=-6.7)$. Like for the previous instrument, also in this case no significant effect is detected in the second stage. The same happens in the overidentified model in column (4). In Table 8 we report the estimates of the same model as above while using an indicator for the household having at least one migrant child as dependent variable. Results on the insignificant effect of sibship size on the migration likelihood at the household level are confirmed.

These findings are consistent with those reported in Section 5.2, pointing to a positive correlation between family size and migration, but excluding a causal effect of the former on the latter. Also in this case, as with individual-level estimates, the larger magnitude of OLS estimates relative to the IV ones points to an upward biased estimate because of endogeneity, i.e. families more likely to send young migrants abroad tend to have more children. 


\section{Gender and Sibling Composition}

\subsection{Migration outcomes as a function of gender and birth order}

In Section 5.1 (Table 3) we find that an individual's probability of migration decreases with birth order. While this is consistent with a household optimal migration model where family's migration returns decrease with child parity, in this and the reminder sections of the paper we present stronger tests on whether migration chances are distributed unevenly - e.g. by age and gender - across children within the same family. Indeed, within a household resources allocation framework, low-parity children may be more likely to migrate because the family has more time to reap the benefits of migration. However, it may still be argued that first-born children are better off with respect to other forms of human capital investments as well. For example, earlier parities may have benefited from higher pre-natal or post-natal parental investments, having shared household resources with fewer siblings, and this may affect the returns to migration. Thus, here we explore the gendered pattern of migration in order to test the hypothesis of the low-parity advantage. In Table 9 we estimate the same regressions as in Table 3 above by adding interaction effects between birth order and gender to the models. ${ }^{34}$

[Table 9 about here]

We observe a negative birth order gradient for boys (the coefficients on the third and higher parities are negative and significant), which is consistent with the average results as in Table 3 above. The interactions of being female with birth order dummies are not statistically significant, suggesting that the birth-order gradient in child migration is not statistically different between boys and girls. Yet, the latter holds for all parities but for firstborns: in column (2) the female main effect shows that female firstborns are significantly less likely to migrate than male firstborns. Overall, these estimates suggest that the chances of migration are not equally distributed across children within the same family. Low-parity children are, in general, more likely to migrate but a firstborn daughter is significantly less likely to

\footnotetext{
${ }^{34}$ As our two-step procedure relies on family fixed effects, when estimating separate regressions by gender only families with at least two sons and at least two daughters can be included in the estimates for males and females, respectively. In order to avoid such a sample selection, we rather adopt a pooled estimation including interaction effects with gender.
} 
migrate than a firstborn son by about 3 p.p. (which means a reduction in the probability of migration of roughly 60 percent at the sample average migration rate). This result, i.e. finding a significant effect on the interaction between first-parity and gender, suggests that it is unlikely that in Mexico parents decide to invest in migration of the firstborns only, irrespective of gender (first-born bias). Also gender turns out to be a significant factor, and in particular (first-born) boys may have higher migration returns than their female peers. This is consistent with a male-dominated Mexican migration phenomenon, as shown by different data (e.g., Cerrutti and Massey 2001). Yet, while parental investment in (low-parity) boys is still a rational choice when returns to migration in the U.S. labor market are higher (or moving costs are lower) for boys than for girls, these findings are also consistent with the argument that parents may just value (low parity) sons more than daughters (preference for

son). Hence, in the next and last sub-section, we estimate the same migration equations as above by allowing a separate effect of sibling composition from the individual gender and birth-order variables. If migration choices are driven by birth-parity or son preference, we should find no separate effect of sibling composition. On the contrary, a significant effect of sibling composition variables on the likelihood to migrate points to the existence of an intrahousehold migration selection process within which some children may have systematically more chances to migrate than others.

\subsection{Migration outcomes as a function of gender and sibling-sex compo- sition}

Our estimates so far show that gender is a robust predictor of migration in Mexican families and, ceteris paribus, boys - especially firstborns - are systematically more likely to migrate abroad than girls. In practice, this means that if migration is costly and not all children are in the position to migrate, a pro-eldest-son migration bias may lead to a situation in which children compete for household resources in order to migrate and such 'rivalry' can yield gains to having relatively more older sisters than brothers (Garg and Morduch 1998). Thus, in order to explore the scope of sibling rivalry by age and gender, we test how sibling composition influences child migration by running two sets of regressions as reported in Table 10. First, we estimate migration equations on the full sample of children as a function of the number of 
their older brothers, while controlling for both family and birth order fixed effects (i.e., conditioning on the number of both siblings and older siblings), child gender, (quadratic) age and cohort dummies. Results in column (1) show that, ceteris paribus, having an older brother (sister) instead of an older sister (brother) decreases (increases) the migration probability by 1.4 p.p. $(t=3.6)$. This result points to a significant role of the gender and age composition of siblings in children's migration outcomes, consistently with a household-level migration strategy. Moreover, the sibling composition effect does not differ significantly by the gender of the child, suggesting that older siblings sex composition equally matters for boys and girls (column 2).

[Table 10 about here]

Yet, we further exploit the gendered migration pattern and the fact that siblings are likely to migrate in order of birth to test whether females pay a toll for higher migration returns for boys. We do so by including a control for having a next-born brother in the family fixed effects regressions on the pooled-sample (with and without interactive effects), as above. If a child has at least one younger sibling, the gender of his/her next-born sibling is random and a comparison of children with next-born brothers with children with next-born sisters, while controlling for older siblings composition, can identify the effect of the sibling's gender. ${ }^{35}$ Results in columns (3) and (4) in Table 10 show that, conditional on older siblings' composition, having a next-born brother does not play any role for sons, but reduces the likelihood to migrate for girls with respect to boys by 1.2 p.p. $(t=-2)$. This result suggests that when parents decide the level of investment in their children's out-migration, the siblings' composition by gender and age matters. More specifically, from our results it seems that a daughter with a next-born brother is less likely to migrate than a girl with a next-born sister. In other words, when parents face the costly decision whether to send a daughter abroad, they seem to prefer to invest in the migration of her next-born brother (if there is one).

All in all, our results are consistent with an optimal household migration strategy where private costs and returns of migration are shared among all siblings. Indeed, a low-parity Mexican boy in the 90s may be more valuable to send as a household migrant abroad than

\footnotetext{
${ }^{35} \mathrm{~A}$ similar empirical strategy is employed by Vogl (2013) to study sibling rivalry over arranged marriages in South Asia.
} 
a girl. In addition, the opportunity cost of sending girls abroad may be higher because they usually take care of chores and family duties at home or are in charge of being close to parents in their elderly age. Hence, social norms or practices combined with market returns on the migration investment may explain the male-dominated pattern of Mexico-U.S. migration and document — similarly to other developing contexts — that young females tend to have less access to human capital investment and enhancing economic opportunities than it is the case for males.

\section{Conclusions}

In this paper we provide novel and rigorous evidence on the extent to which international labor mobility is affected by the demographic characteristics of the migrant's origin household. Migration is largely a youth phenomenon that occurs in households that seldom dispatch all of their children to work abroad. With capital market imperfections and high migration costs, the 'resource dilution' hypothesis predicts that a larger sibship size will decrease the chances of offspring's migration. Yet, in relatively poor contexts, parents are likely to depend on their grown-up children for the provision of care and income, and high migration opportunities can significantly contribute to the living arrangements of elderly parents.

We use data on teenagers and young adults from a rich household survey to examine the causal effects of sibship size, birth order and sibling composition on migration outcomes in Mexico. Mexican migration, mainly to the U.S., is an enduring flow that accounts for one third of total U.S. immigration and one-tenth of the entire population born in Mexico. Importantly, migration patterns in the 90s differ by age and gender, with a significant fraction of Mexican males migrating between the ages of 15 and 25 .

We focus on the determinants of adolescents' and young adults' migration in Mexico. Our large dataset allows us to overcome the limitations of small samples of children, and it includes detailed information on both women's fertility and the migration histories of household members.' We find no evidence that high fertility (i.e. large family size) has a causal impact on migration. The positive link between family size and migration breaks down when potential endogeneity is addressed using biological fertility and infertility shocks. On the other hand, we find differences in the chances of migration between siblings within the 
same family. Older siblings, especially firstborn males, are more likely to migrate, while having relatively more older brothers than sisters systematically decreases the likelihood of migration of all children. Yet, girls, but not boys, are less likely to migrate when their next parity is a male.

Our findings are consistent with a household's optimal migration model in which parents maximize returns to migration when deciding on whether to have one or more of their children to move abroad. Large family size does not constitute per se a significant push factor in the migration choice, whilst gender, birth order and sibling composition have much more influence on the migration outcome. In particular, in resource-scarce contexts, girls' migration can be viewed as less economically rewarding and more socially costly to parents, with the result that boys end up having more economic opportunities than girls, even through migration.

These results contribute to the migration literature by shedding new light on the role of the family in determining international migration choices. Labor mobility, especially from poor to rich settings, is one of the most important ways through which young adults can expand their productivity and earning potentials. The type of family-based migration from Mexico to the U.S. during the 1990s is of substantial and growing importance for many today's developing countries (e.g., in Asia and Africa) that are currently affected by both high fertility rates and international migration (e.g., Hatton and Williamson 2003). Despite the easily observable association between high fertility rates and migration, we provide evidence that large families are unlikely to be a systematic driver of migration. This finding is in line with recent evidence showing that high fertility in developing contexts is not necessarily bad for children's economic outcomes (e.g., Qian 2009).

Understanding the link between fertility and migration is also relevant today since many governments in developing countries have attempted to curb population growth as a means of increasing the average human capital investment and possibly reducing migration (e.g., China and India, the world's two most populous countries, have experimented with different family planning policies to control family size). Yet, although our empirical findings do not point to a causal link between family size and migration, they hint to the fact that parental investment in offspring's migration may matter for lifetime fertility choices. Moreover, by showing that not all children within the family have the same chance to migrate, our findings 
point to the existence of an optimal intra-household selection process into migration. This is so as in contexts of scarce resources and weak formal safety nets, children may be a key social security valve for parents such that high migration opportunities to rich countries may increase the value of children (some of them in particular, e.g., first-born sons). Hence, effective family welfare measures or even the development of credit and insurance markets may lead to a reduction in both migration and fertility, and also perhaps a lesser (gender) inequality. 


\section{References}

Agüero, J. M. and M. S. Marks (2008). Motherhood and female labor force participation: Evidence from infertility shocks. American Economic Review 98(2), 500-504.

Agüero, J. M. and M. S. Marks (2011). Motherhood and female labor supply in the developing world: Evidence from infertility shocks. Journal of Human Resources 46(4), 800-826.

Amuedo-Dorantes, C. and S. Pozo (2011). Remittances and income smoothing. The American Economic Review, Papers and Proceedings 102(3), 582-587.

Angrist, J., V. Lavy, and A. Schlosser (2010). Multiple experiments for the causal link between the quantity and quality of children. Journal of Labor Economics 28(4), $773-$ 824.

Angrist, J. D. and W. N. Evans (1998, June). Children and Their Parents' Labor Supply: Evidence from Exogenous Variation in Family Size. American Economic Review 88(3), $450-477$.

Antman, F. (2012). Elderly care and intrafamily resource allocation when children migrate. Journal of Human Resources 47(2), 331-63.

Ashenfelter, O. (2012). Comparing real wage rates: Presidential address. American Economic Review 102(2), 617-42.

Bagger, J., J. Birchenall, H. Mansour, and S. Urzúa (2013). Education, birth order, and family size. NBER Working Papers 19111, National Bureau of Economic Research, Inc.

Becker, G. S. (1960). An economic analysis of fertility. In G. S. Becker (Ed.), Demographic and Economic Change in Developed Countries, . Princeton, NJ: Princeton University Press.

Becker, G. S. and H. Lewis (1973). On the interaction between the quantity and quality of children. Journal of Political Economy 81(2), S279-S288.

Becker, G. S. and N. Tomes (1976). Child endowments and the quantity and quality of children. Journal of Political Economy 84(4), S143-62.

Billari, F. C. and V. Galasso (2014). Fertility decisions and pension reforms. Evidence from natural experiments in Italy. IdEP Economic Papers 1403, USI Università della Svizzera italiana.

Black, S. E., P. J. Devereux, and K. G. Salvanes (2005). The more the merrier? The effect of family size and birth order on children's education. The Quarterly Journal of Economics, $669-700$.

Borjas, G. J. and L. F. Katz (2007, May). The evolution of the mexican-born workforce in the United States. In G. J. Borjas (Ed.), Mexican Immigration to the United States, pp. 13-56. Chicago: University of Chicago Press.

Bratti, M. and L. Cavalli (2014). Delayed first birth and new mothers' labor market outcomes: Evidence from biological fertility shocks. European Journal of Population 30(1), $35-63$. 
Brezis, E. S. and R. D. S. Ferreira (2016). Endogenous fertility with a sibship size effect. Macroeconomic Dynamics 20(8), 2046-2066.

Buck, G. M., L. E. Sever, R. E. Batt, and P. Mendola (1997). Life-style factors and female infertility. Epidemiology 8(4), 435-441.

Cabrera, G. (1994). Demographic dynamics and development: The role of population policy in Mexico. Population and Development Review 20, 105-120.

Càceres-Delpiano, J. (2006). The impacts of family size on investment in child quality. Journal of Human Resources 41(4), 738-754.

Casterline, J. (1989). Collecting data on pregnancy loss: A review of evidence from the World Fertility Survey. Studies in Family Planning 20(2), 81-95.

Cerrutti, M. and D. Massey (2001). On the auspices of female migration from Mexico to the United States. Demography 38(2), 187-200.

Chen, J. J. (2006). Migration and imperfect monitoring: Implications for intra-household allocation. American Economic Review 96(2), 227-231.

Chen, K.-P., S.-H. Chiang, and S. F. Leung (2003). Migration, family, and risk diversification. Journal of Labor Economics 21(2), 323-352.

Cigno, A. (1993). Intergenerational transfers without altruism: Family, market and state. European Journal of Political Economy 9(4), 505-518.

Clemens, M. (2011). Economics and emigration: Trillion-dollar bills on the sidewalk? Journal of Economic Perspectives 25(3), 83-106.

Clemens, M., C. E. Montenegro, and L. Pritchett (2010). The place premium: Wage differences for identical workers across the us border. Working papers, University of Chile, Department of Economics.

Clemens, M. A., Ç. Özden, and H. Rapoport (2015). Reprint of: Migration and development research is moving far beyond remittances. World Development 65, 1-5.

De Haan, M., P. E. and J. Rosero (2014). Birth order and human capital development: Evidence from Ecuador. Journal of Human Resources 49(2), 359-392.

Duflo, E. and A. Banerjee (2011). Poor Economics: A Radical Rethinking of the Way to Fight Global Poverty. PublicAffairs.

Dustmann, C. and A. Glitz (2011). Migration and education. In E. Hanushek, S. Machin, and L. Woessmann (Eds.), Handbook of the Economics of Education, Volume 4, Chapter Chapter 4, pp. 327-439. Amsterdam: Elsevier.

Fitzsimons, E. and B. Malde (2014). Empirically probing the quantity-quality model. Journal of Population Economics 27(1), 33-68.

Gábos, A., G. R. and G. Kézdi (2009). The effects of child-related benefits and pensions on fertility. Population Studies 63(3), 215-231.

Garg, A. and J. Morduch (1998). Sibling rivalry and the gender gap: Evidence from child health outcomes in Ghana. Journal of Population Economics 11(4), 471-493. 
Ghatak, S., P. L. and S. W. Price (1996). Migration theories and evidence: An assessment. Journal of Economic Surveys 10(2), 159-197.

Gibson, J. and D. McKenzie (2012). The economic consequences of 'brain drain' of the best and brightest: Microeconomic evidence from five countries. The Economic Journal 122(560), 339-375.

Giles, J. and R. Mu (2007). Elderly parent health and the migration decisions of adult children: Evidence from rural China. Demography 44(2), 265-288.

Hanson, G. (2004). Illegal migration from Mexico to the United States. Journal of Economic Literature Vol. 44(4), 869-924.

Hanson, G. H. and C. McIntosh (2010). The Great Mexican migration. The Review of Economics and Statistics 92(4), 798-810.

Hanushek, E. A. (1992). The trade-off between child quantity and quality. Journal of Political Economy 100(1), 84-117.

Hatton, T. J. and J. G. Williamson (1998). The Age of Mass Migration: Causes and Economic Impact. New York: Oxford University Press.

Hatton, T. J. and J. G. Williamson (2003). Demographic and economic pressure on emigration out of Africa. Scandinavian Journal of Economics 105(3), 465-486.

Hotz, V. J., S. W. McElroy, and S. G. Sanders (2005). Teenage childbearing and its life cycle consequences: Exploiting a natural experiment. Journal of Human Resources 40(3), $683-715$.

Jayachandran, S. and I. Kuziemko (2011). Why do mothers breastfeed girls less than boys? evidence and implications for child health in india. The Quarterly journal of economics 126(3), 1485-1538.

Jayachandran, S. and R. Pande (2015). Why are Indian Children so short? NBER Working Papers 21036, National Bureau of Economic Research, Inc.

Jensen, R. and N. Miller (2011). Keepin' 'em down on the farm: Old age security and strategic underinvestment in children. mimeo UCLA.

Joffe, M. and I. Barnes (2000). Do parental factors affect male and female fertility? Epidemiology 11(6), 700-705.

Karimi, A. (2014, August). Effects of the timing of births on women's earnings - Evidence from a natural experiment. Working Paper Series 2014:17, IFAU - Institute for Evaluation of Labour Market and Education Policy.

Kennan, J. and J. R. Walker (2011). The effect of expected income on individual migration decisions. Econometrica 79(1), 211-251.

Lewis, J. B. and D. A. Linzer (2005). Estimating regression models in which the dependent variable is based on estimates. Political Analysis 13(4), 345-364.

Lucas, R. E. B. and O. Stark (1985). Motivations to remit: Evidence from Botswana. Journal of Political Economy 93(5), 901-18. 
Markussen, S. and M. Strøm (2015). The effects of motherhood. Technical report, MEMORANDUM No 19/2015, Department of Economics, University of Oslo.

Martin, P. L. (1993). Trade and Migration: NAFTA and Agriculture. Washington: Institute for International Economics.

Mckenzie, D. and H. Rapoport (2007). Network effects and the dynamics of migration and inequality: Theory and evidence from Mexico. Journal of Development Economics 84(1), $1-24$.

Miller, A. (2011). The effect of motherhood timing on career path. Journal of Population Economics 24(3), 1071-1100.

Miller, G. and K. S. Babiarz (2014). Family Planning: Program Effects. NBER Working Papers 20586, National Bureau of Economic Research, Inc.

Mourard, E. (2015). The impact of migration on the family left behind: Estimation in presence of intra-household selection of the migrants. Paris School of Economics. Mimeo.

Nugent, J. (1985). The old-age security motive for fertility. Population and Development Review 11(1), 75-97.

Ozden, C. and M. Schiff (2006). International Migration, Remittances, and the Brain Drain. Washington, DC: The World Bank and Palgrave McMillan.

Pande, R. (2003). Selective gender differences in childhood nutrition and immunization in rural India: The role of siblings. Demography 40(3), 395-418.

Parish, W. L. and R. J. Willis (1993). Daughters, education, and family budgets Taiwan experiences. Journal of Human Resources 28(4), 863-898.

Platteau, J. (1991). Traditional systems of social security and hunger insurance: Past achievements and modern challenges. Clarendon Press, Oxford.

Plouffe, L. J., T. S. White E. W., C. Sweet, L. Layman, G. Whitman, and P. McDonough (1992). Etiologic factors of recurrent abortion and subsequent reproductive performance of couples: Have we made any progress in the past 10 years? American Journal of Obstetrics and Gynecology 167(2), 313-321.

Qian, N. (2009). Quantity-quality and the one child policy:the only-child disadvantage in school enrollment in rural China. NBER Working Papers 14973, National Bureau of Economic Research, Inc.

Rapoport, H. and F. Docquier (2006, 00). The Economics of Migrants' Remittances, Volume 1 of Handbook on the Economics of Giving, Reciprocity and Altruism, Chapter 17, pp. 1135-1198. Elsevier.

Ratha, D., S. Mohapatra, and E. Scheja (2011). Impact of migration on economic and social development: A review of evidence and emerging issues. Policy Research Working Paper Series 5558, The World Bank (3).

Ray, D. (1998). Development Economics. Princeton, NJ: Princeton University Press.

Rosenzweig, M. (2007). Education and migration: A global perspective. Yale University. Mimeo. 
Rosenzweig, M. R. (1988). Risk, implicit contracts and the family in rural areas of lowincome countries. Economic Journal 98(393), 1148-70.

Rosenzweig, M. R. and O. Stark (1989). Consumption smoothing, migration, and marriage: Evidence from rural India. Journal of Political Economy 97(4), 905-26.

Rosenzweig, M. R. and K. I. Wolpin (1980). Testing the quantity-quality fertility model: The use of twins as a natural experiment. Econometrica 48(1), 227-240.

Schultz, T. (2008a). Population policies, fertility, women's human capital, and child quality. Volume 4, Chapter 52, pp. 3249-3303. Amsterdam: Elsevier.

Schultz, T. P. (1990). Testing the neoclassical model of family labor supply and fertility. Journal of Human Resources 25(4), 599-634.

Schultz, T. P. (2008b). Population policies, fertility, women's human capital, and child quality, Volume 4 of Handbook of Development Economics, Chapter 52, pp. 3249-3303. Elsevier.

Sjaastad, L. (1962). The costs and returns of human migration. Journal of Political Economy 70(5), 80-93.

Stark, O. (1981). The asset demand for children during agricultural moderninzation. Population and Development Review 4(3), 671-675.

Stark, O. (1991). The migration of labour. Basil Blackwell, Cambridge.

Stark, O. and D. E. Bloom (1985). The new economics of labor migration. American Economic Review 75(2), 173-78.

Stohr, T. (2015). Siblings' interaction in migration decisions: who provides for the elderly left behind? Journal of Population Economics 28(3), 593-629.

Suits, D. B. (1984). Dummy variables: Mechanics v. interpretation. The Review of Economics and Statistics 66(1), 177-80.

Thomas, D. (1990). Intra-household resource allocation: An inferential approach. Journal of Human Resources 25(4), 635-664.

UN (2013). World youth report. Technical report, United Nations.

UNDESA (2011). The age and sex of migrants. Technical report, United Nation, Department of Economics and Social Affairs, Population Division.

Vogl, T. S. (2013). Marriage institutions and sibling competition: Evidence from south Asia. The Quarterly Journal of Economics 128(3), 1017-1072.

Wilcox, L. S. and W. D. Mosher (1993). Use of infertility services in the United States. Obstetrics \& Gynecology 82(1), 122-127.

Williamson, J. (1990). Coping with City Growth during the British Industrial Revolution. Cambridge, MA: Harvard University Press.

Yang, D. (2008). International migration, remittances and household investment: Evidence from Philippine migrants' exchange rate shocks. Economic Journal 118(528), 591-630. 
Zuniga Herrera, E. (2008). Population policy in Mexico and its relationship to development. presented at Contribution of Population Policy to the Achievement of the Internationally Development Goals including the MDGs. Panel discussion, New York, 15 December 2008. 
Figure 1: Distribution of Mexican individual (non-tied) migration by age and gender

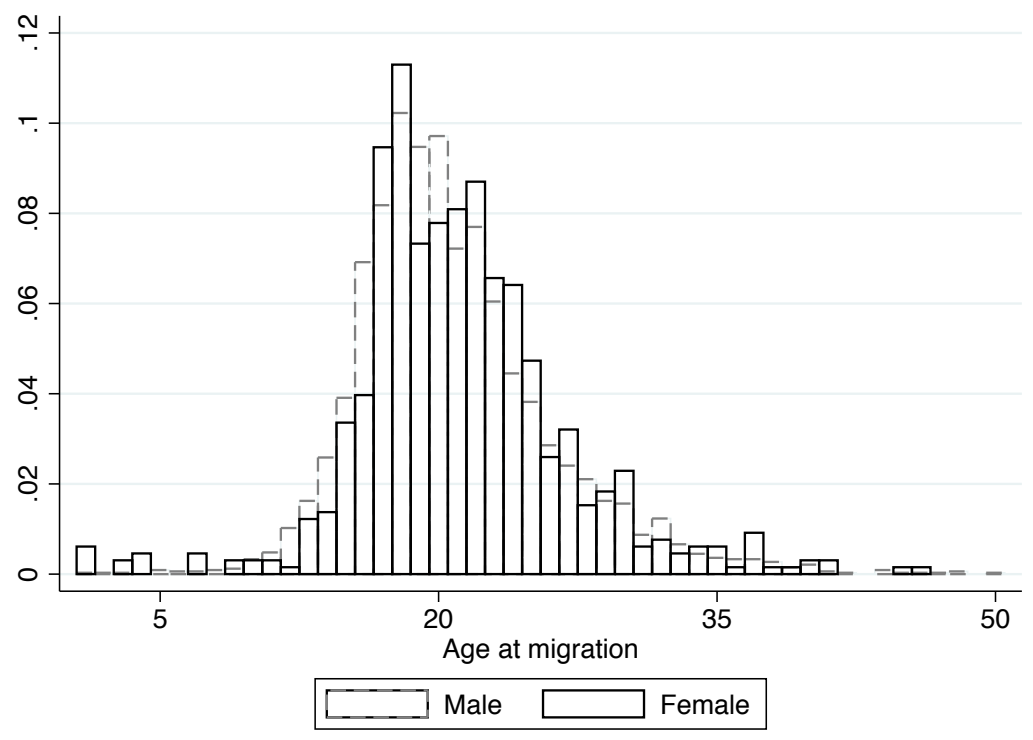

Source: Our computations on ENADID, 1992 and 1997.

Figure 2: Individual migration rate by family size

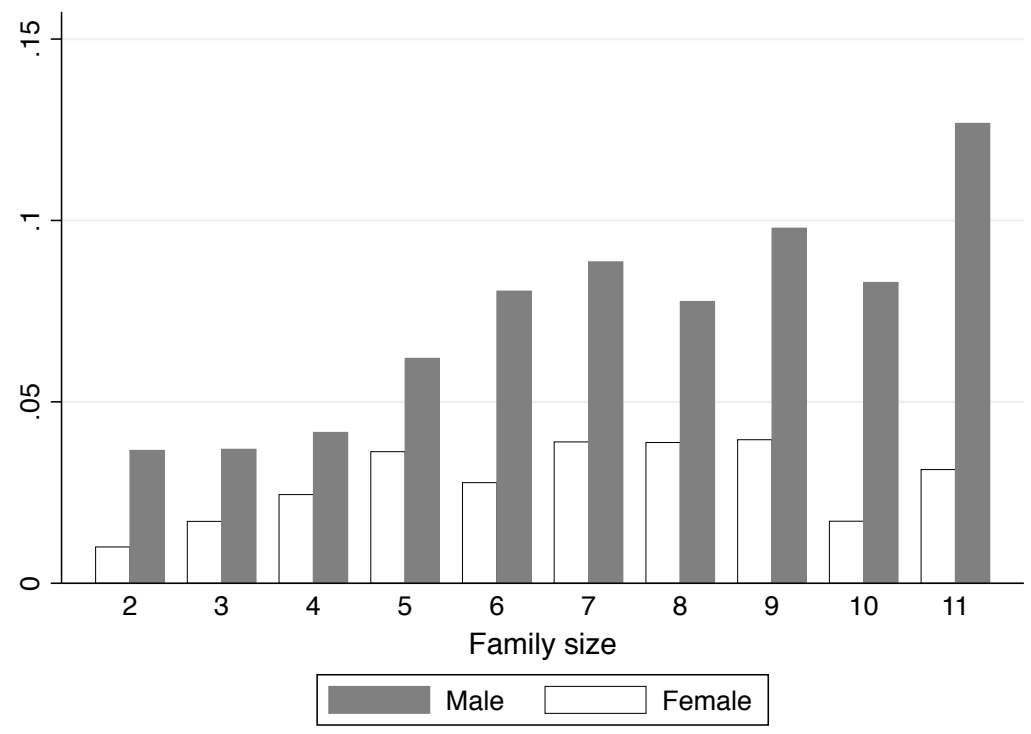

Source: Our computations on ENADID, 1992 and 1997. 
Figure 3: Average number of children by women's infertility shock status

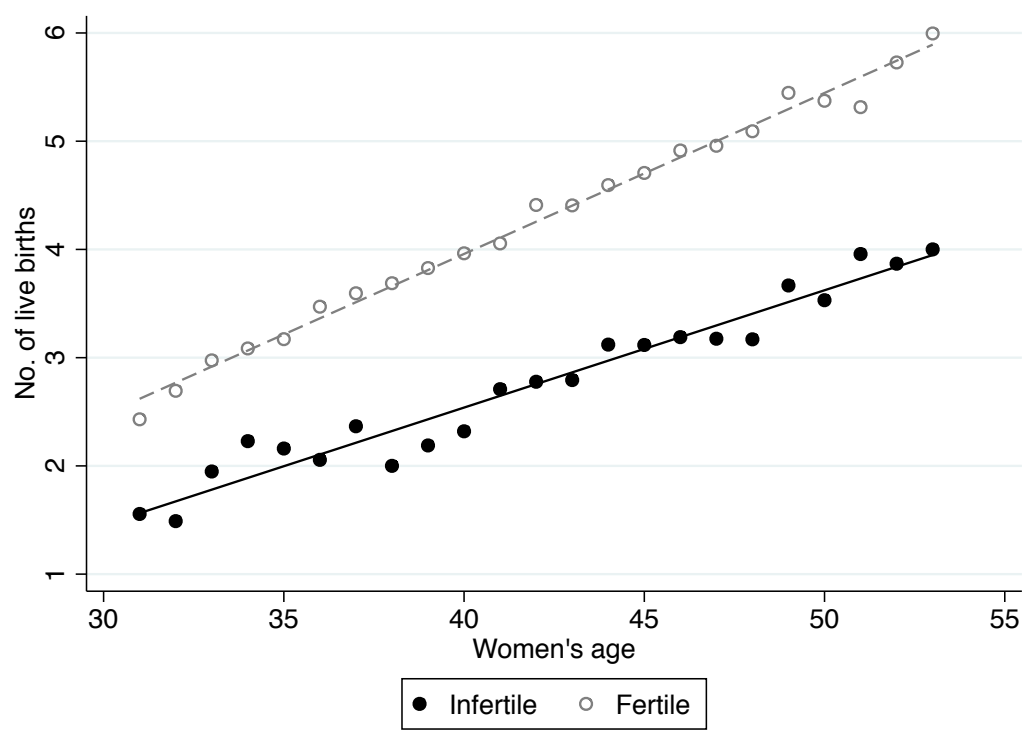

Note. Source: ENADID, 1992 and 1997. The figure reports the average number of live births by women's infertility shock status and age. Regression lines are super-imposed to the cross-plot.

Figure 4: Average number of children by women's miscarriage at first pregnancy

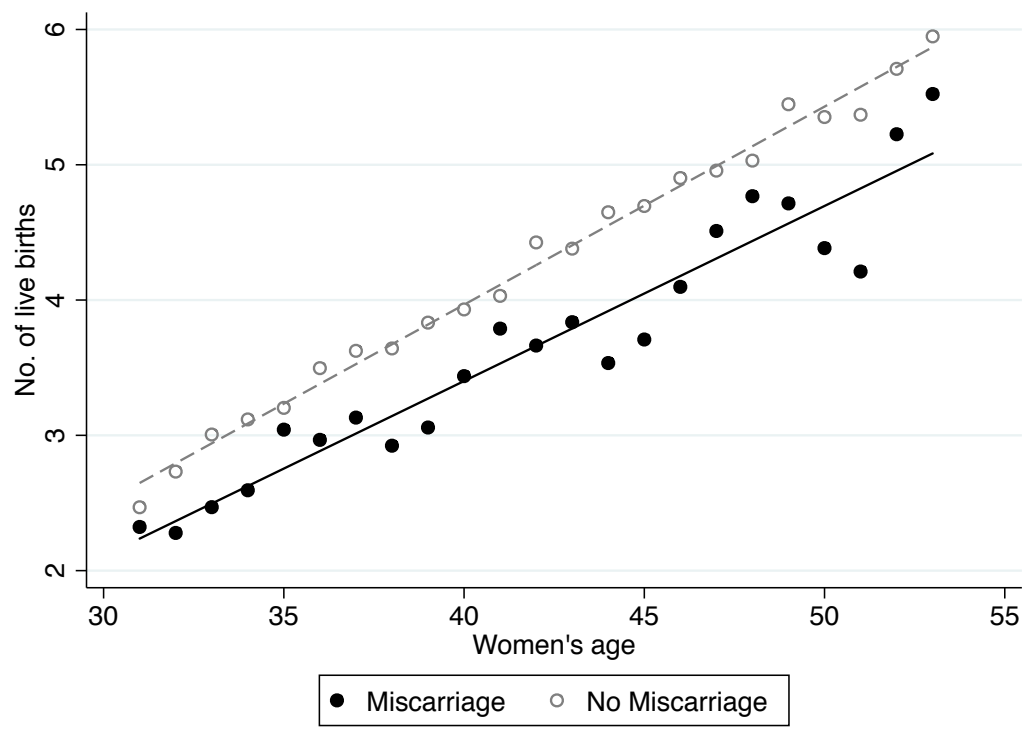

Note. Source: ENADID, 1992 and 1997. The figure reports the average number of live births by miscarriage at first pregnancy and age. Regression lines are super-imposed to the cross-plot. 
Table 1: Sample characteristics by migration status

\begin{tabular}{|c|c|c|c|}
\hline & $\begin{array}{c}\text { Non-migrants } \\
\text { (A) }\end{array}$ & $\begin{array}{l}\text { Migrants } \\
\text { (B) }\end{array}$ & $\begin{array}{c}p-\text { values } \\
(\mathrm{A})-(\mathrm{B})\end{array}$ \\
\hline \multicolumn{4}{|l|}{ Individual-level characteristics } \\
\hline Age & 18.878 & 20.982 & 0.000 \\
\hline Female & 0.458 & 0.250 & 0.000 \\
\hline N. of siblings & 5.071 & 5.869 & 0.000 \\
\hline Birth order 1 & 0.181 & 0.192 & 0.300 \\
\hline Birth order 2 & 0.231 & 0.225 & 0.555 \\
\hline Birth order 3 & 0.178 & 0.178 & 0.978 \\
\hline Birth order 4 & 0.137 & 0.154 & 0.077 \\
\hline Birth order 5 & 0.102 & 0.102 & 0.993 \\
\hline Birth order 6 & 0.071 & 0.073 & 0.781 \\
\hline Birth order 7 & 0.046 & 0.041 & 0.343 \\
\hline Birth order 8 & 0.028 & 0.021 & 0.100 \\
\hline Birth order 9 & 0.014 & 0.009 & 0.121 \\
\hline Birth order $10+$ & 0.011 & 0.006 & 0.107 \\
\hline \multicolumn{4}{|l|}{ Household-level characteristics } \\
\hline Mother's age & 44.612 & 46.171 & 0.000 \\
\hline Mother's age at first pregnancy & 20.030 & 19.699 & 0.182 \\
\hline Mother's years of schooling & 4.091 & 3.452 & 0.010 \\
\hline Mother chronic illness & 0.023 & 0.008 & 0.131 \\
\hline Single mother & 0.185 & 0.188 & 0.896 \\
\hline Household Wealth Index ${ }^{(a)}$ & -0.012 & 0.087 & 0.003 \\
\hline Father's age & 48.799 & 52.207 & 0.000 \\
\hline Father's years of schooling & 4.931 & 3.789 & 0.059 \\
\hline
\end{tabular}

Note. Source: ENADID, 1992 and 1997. The estimation sample includes individuals aged 15-25 whose mothers are not using contraceptive methods. The sample comprises 1,394 migrants and 25,349 non-migrant individuals. ${ }^{(a)}$ The index is constructed by using Principal Component Analysis and information on household's type of floor and toilette, and access to water and electricity.

Table 2: Incidence of fertility and infertility shocks by sibship size

\begin{tabular}{|c|c|c|c|c|c|c|c|}
\hline \multicolumn{4}{|c|}{ Individual sample } & \multicolumn{4}{|c|}{ Household sample } \\
\hline \multirow[b]{2}{*}{ sibship size } & \multirow[b]{2}{*}{$\%$} & \multicolumn{2}{|c|}{ Incidence of shock (\%) } & \multirow[b]{2}{*}{ sibship size } & \multirow[b]{2}{*}{$\%$} & \multicolumn{2}{|c|}{ Incidence of shock (\%) } \\
\hline & & infertility & miscarriage & & & infertility & miscarriage \\
\hline & & & & 0 & 3.69 & 13.37 & 5.05 \\
\hline 1 & 4.59 & 11.56 & 6.03 & 1 & 9.84 & 11.43 & 6.80 \\
\hline 2 & 12.16 & 8.33 & 5.38 & 2 & 16.88 & 7.48 & 5.20 \\
\hline 3 & 14.20 & 5.45 & 4.06 & 3 & 15.96 & 5.16 & 4.02 \\
\hline 4 & 14.68 & 5.12 & 4.05 & 4 & 13.66 & 4.30 & 3.86 \\
\hline 5 & 13.54 & 4.00 & 5.55 & 5 & 11.20 & 3.73 & 4.71 \\
\hline $6+$ & 40.82 & 3.94 & 3.68 & $6+$ & 28.76 & 3.51 & 3.44 \\
\hline & 100.00 & & & & 100.00 & & \\
\hline
\end{tabular}

Note. The table reports the incidence of fertility and infertility shocks in the estimation samples used in the individual-level (see Section 5.2) and the household-level analysis (see Section 5.3 ), respectively. 
Table 3: Birth order effects

\begin{tabular}{|c|c|c|}
\hline Variables & (1) & (2) \\
\hline female & $\begin{array}{c}-0.036 * * * \\
(0.003)\end{array}$ & $\begin{array}{c}-0.035^{*} * * \\
(0.003)\end{array}$ \\
\hline birth order & $\begin{array}{c}-0.019 * * * \\
(0.003)\end{array}$ & \\
\hline birth order 2 & & $\begin{array}{l}-0.002 \\
(0.005)\end{array}$ \\
\hline birth order 3 & & $\begin{array}{c}-0.021 * * * \\
(0.007)\end{array}$ \\
\hline birth order 4 & & $\begin{array}{c}-0.038 * * * * \\
(0.010)\end{array}$ \\
\hline birth order 5 & & $\begin{array}{c}-0.068 * * * \\
(0.013)\end{array}$ \\
\hline birth order 6 & & $\begin{array}{c}-0.086^{* * *} \\
(0.016)\end{array}$ \\
\hline birth order 7 & & $\begin{array}{c}-0.112 * * * \\
(0.019)\end{array}$ \\
\hline birth order 8 & & $\begin{array}{c}-0.136 * * * \\
(0.022)\end{array}$ \\
\hline birth order 9 & & $\begin{array}{c}-0.161 * * * * \\
(0.026)\end{array}$ \\
\hline birth order $10+$ & & $\begin{array}{c}-0.199 * * * * \\
(0.030)\end{array}$ \\
\hline age & $\begin{array}{c}0.020 * * \\
(0.009)\end{array}$ & $\begin{array}{c}0.021 * * \\
(0.009)\end{array}$ \\
\hline age squared & $\begin{array}{c}0.000 \\
(0.000)\end{array}$ & $\begin{array}{c}0.000 \\
(0.000)\end{array}$ \\
\hline Year of birth indicators & YES & YES \\
\hline Family fixed effects & YES & YES \\
\hline Observations & 26,743 & 26,743 \\
\hline R-squared & 0.050 & 0.052 \\
\hline
\end{tabular}

Note. The dependent variable is a dichotomous indicator of the child's migration status. The model is estimated using OLS. Sibship size is absorbed by family fixed effects. Standard errors clustered at the household level in parentheses. $* * *$ and $* * *$ denote statistical significance at 10,5 and 1 percent level, respectively. 
Table 4: Sibship size effect: WLS estimates

\begin{tabular}{|c|c|c|c|c|c|c|c|}
\hline Variables & (1) & (2) & (3) & (4) & (5) & (6) & (7) \\
\hline N. siblings & $\begin{array}{c}0.011 * * * \\
(0.001)\end{array}$ & $\begin{array}{c}0.011 * * * \\
(0.001)\end{array}$ & $\begin{array}{c}0.014 * * * \\
(0.001)\end{array}$ & $\begin{array}{c}0.010 * * * \\
(0.001)\end{array}$ & $\begin{array}{c}0.013 * * * \\
(0.001)\end{array}$ & $\begin{array}{c}0.010 * * * \\
(0.001)\end{array}$ & $\begin{array}{c}0.013 * * * \\
(0.001)\end{array}$ \\
\hline N. siblings $\times$ female & & & $\begin{array}{c}-0.008 * * * \\
(0.001)\end{array}$ & & $\begin{array}{c}-0.007 * * * \\
(0.001)\end{array}$ & & $\begin{array}{c}-0.006 * * * \\
(0.001)\end{array}$ \\
\hline female & & $\begin{array}{c}-0.038 * * * \\
(0.003)\end{array}$ & $\begin{array}{c}-0.036 * * * \\
(0.006)\end{array}$ & $\begin{array}{c}-0.033 * * * \\
(0.003)\end{array}$ & $\begin{array}{c}-0.031 * * * \\
(0.006)\end{array}$ & $\begin{array}{c}-0.033^{* * *} * \\
(0.003)\end{array}$ & $\begin{array}{c}-0.031 * * * \\
(0.003)\end{array}$ \\
\hline Individual's controls & $\mathrm{NO}$ & YES & YES & YES & YES & YES & YES \\
\hline Mother's controls & $\mathrm{NO}$ & NO & NO & YES & YES & YES & YES \\
\hline Father's controls & $\mathrm{NO}$ & $\mathrm{NO}$ & NO & YES & YES & YES & YES \\
\hline Municipality indicators & NO & $\mathrm{NO}$ & $\mathrm{NO}$ & NO & $\mathrm{NO}$ & YES & YES \\
\hline Observations & 26,743 & 26,743 & 26,743 & 26,743 & 26,743 & 26,743 & 26,743 \\
\hline R-squared & 0.013 & 0.054 & 0.055 & 0.177 & 0.178 & 0.202 & 0.203 \\
\hline
\end{tabular}

Note. The dependent variable is netted migration (see Section 4). The model is estimated using Weighted Least Squares (weights are the inverse of the standard errors of netted migration). Individual's controls include year of birth indicators, age, age squared; mother's controls include year of birth indicators, age and age squared, age at first pregnancy, years of schooling, indicators for mother's chronic illness and being single; father's controls include decade of birth indicators, age and age squared, years of schooling. Standard errors clustered at the household level in parentheses. ${ }^{*} * *$ and $* * *$ denote statistical significance at 10, 5 and 1 percent level, respectively.

Table 5: Sibliship size effect: 2SLS estimates

\begin{tabular}{|c|c|c|c|}
\hline Variables & (1) & (2) & (3) \\
\hline \multicolumn{4}{|l|}{ Second stage } \\
\hline N. siblings & $\begin{array}{c}0.004 \\
(0.014)\end{array}$ & $\begin{array}{l}-0.018 \\
(0.023)\end{array}$ & $\begin{array}{l}-0.005 \\
(0.012)\end{array}$ \\
\hline female & $\begin{array}{c}-0.033^{* * * *} \\
(0.003)\end{array}$ & $\begin{array}{c}-0.033 * * * \\
(0.003)\end{array}$ & $\begin{array}{c}-0.033 * * * \\
(0.003)\end{array}$ \\
\hline IV: & infertility & miscarriage & overidentified \\
\hline Anderson-Rubin $F$-statistic & $\begin{array}{c}0.073 \\
{[0.787]}\end{array}$ & $\begin{array}{c}0.686 \\
{[0.407]}\end{array}$ & $\begin{array}{c}0.389 \\
{[0.678]}\end{array}$ \\
\hline Hansen $J$-statistic & & & $\begin{array}{c}0.737 \\
{[0.391]}\end{array}$ \\
\hline First stage $-N$. siblings & & & \\
\hline infertility & $\begin{array}{c}-0.494 * * * \\
(0.095)\end{array}$ & & $\begin{array}{c}-0.491 * * * \\
(0.095)\end{array}$ \\
\hline miscarriage & & $\begin{array}{c}-0.437 * * * \\
(0.10)\end{array}$ & $\begin{array}{c}-0.433 * * * \\
(0.10)\end{array}$ \\
\hline Angrist-Pischke $F$-statistic instrument(s) & 26.90 & 19.13 & 23.37 \\
\hline Individual's controls & YES & YES & YES \\
\hline Mother's controls & YES & YES & YES \\
\hline Father's controls & YES & YES & YES \\
\hline Municipality indicators & YES & YES & YES \\
\hline Observations & 26,743 & 26,743 & 26,743 \\
\hline
\end{tabular}

Note. The dependent variable is netted migration (see Section 4). Observations are weighted by the inverse of the standard error of netted migration. The list of control variables is the same as in Table 4. Standard errors clustered at the household level in parentheses. $P$-values are reported in brackets. *** and *** denote statistical significance at 10, 5 and 1 percent level, respectively. 
Table 6: Child gender and sibship size effect: 2SLS estimates

\begin{tabular}{|c|c|c|c|}
\hline Variables & (1) & (2) & (3) \\
\hline \multicolumn{4}{|l|}{ Second stage } \\
\hline N. siblings & $\begin{array}{c}0.005 \\
(0.016)\end{array}$ & $\begin{array}{l}-0.065 \\
(0.048)\end{array}$ & $\begin{array}{l}-0.007 \\
(0.015)\end{array}$ \\
\hline N. siblings $\times$ female & $\begin{array}{l}-0.005 \\
(0.013)\end{array}$ & $\begin{array}{c}0.112 \\
(0.079)\end{array}$ & $\begin{array}{c}0.005 \\
(0.013)\end{array}$ \\
\hline female & $\begin{array}{c}-0.032 * * * \\
(0.004)\end{array}$ & $\begin{array}{c}-0.064 * * * \\
(0.022)\end{array}$ & $\begin{array}{c}-0.034 * * * \\
(0.005)\end{array}$ \\
\hline IV: & infertility & miscarriage & overidentified \\
\hline Anderson-Rubin $F$-statistic & $\begin{array}{c}0.074 \\
{[0.928]}\end{array}$ & $\begin{array}{c}2.210 \\
{[0.110]}\end{array}$ & $\begin{array}{c}1.150 \\
{[0.331]}\end{array}$ \\
\hline Hansen $J$-statistic & & & $\begin{array}{c}4.399 \\
{[0.111]}\end{array}$ \\
\hline First stage $-N$. siblings & & & \\
\hline infertility & $\begin{array}{c}-0.567 * * * \\
(0.109)\end{array}$ & & $\begin{array}{c}-0.564 * * * \\
(0.108)\end{array}$ \\
\hline infertility $\times$ female & $\begin{array}{c}0.168 \\
(0.115)\end{array}$ & & $\begin{array}{c}0.169 \\
(0.115)\end{array}$ \\
\hline miscarriage & & $\begin{array}{c}-0.453 * * * \\
(0.117)\end{array}$ & $\begin{array}{c}-0.450 * * * \\
(0.117)\end{array}$ \\
\hline miscarriage $\times$ female & & $\begin{array}{c}0.037 \\
(0.106)\end{array}$ & $\begin{array}{c}0.038 \\
(0.105)\end{array}$ \\
\hline Angrist-Pischke $F$-statistic instrument(s) & 28.62 & 11.98 & 15.68 \\
\hline $\begin{array}{l}\text { First stage }-N \text {. siblings } \times \text { female } \\
\text { infertility }\end{array}$ & $0.125 * * *$ & & $0125 * * *$ \\
\hline & $(0.038)$ & & $(0.038)$ \\
\hline infertility $\times$ female & $\begin{array}{c}-0.694 * * * \\
(0.131)\end{array}$ & & $\begin{array}{c}-0.691 * * * \\
(0.131)\end{array}$ \\
\hline miscarriage & & $\begin{array}{l}-0.067 \\
(0.044)\end{array}$ & $\begin{array}{l}-0.068 \\
(0.043)\end{array}$ \\
\hline miscarriage $\times$ female & & $\begin{array}{c}-0.261 * * \\
(0.131)\end{array}$ & $\begin{array}{l}-0.254 * \\
(0.130)\end{array}$ \\
\hline Angrist-Pischke $F$-statistic instrument(s) & 26.93 & 4.27 & 13.83 \\
\hline Individual's controls & YES & YES & YES \\
\hline Mother's controls & YES & YES & YES \\
\hline Father's controls & YES & YES & YES \\
\hline Municipality indicators & YES & YES & YES \\
\hline Observations & 26,743 & 26,743 & 26,743 \\
\hline
\end{tabular}

Note. The dependent variable is netted migration (see Section 4). Observations are weighted by the inverse of the standard error of netted migration. The list of control variables is the same as in Table 4. Standard errors clustered at the household level in parentheses. $P$-values are reported in brackets. *** and *** denote statistical significance at 10, 5 and 1 percent level, respectively. 
Table 7: Family size effect on the number of migrants: Household-level estimates

\begin{tabular}{|c|c|c|c|c|}
\hline Variables & $\begin{array}{c}\text { (1) } \\
\text { OLS }\end{array}$ & $\begin{array}{c}(2) \\
2 \text { SLS }\end{array}$ & $\begin{array}{c}(3) \\
2 \text { SLS }\end{array}$ & $\begin{array}{c}(4) \\
\text { 2SLS }\end{array}$ \\
\hline $\begin{array}{l}\text { Second stage } \\
\text { N. children }\end{array}$ & $\begin{array}{l}0.020 * * * \\
(0.002)\end{array}$ & $\begin{array}{l}-0.004 \\
(0.015)\end{array}$ & $\begin{array}{l}-0.031 \\
(0.031)\end{array}$ & $\begin{array}{l}-0.011 \\
(0.014)\end{array}$ \\
\hline $\begin{array}{l}\text { IV: } \\
\text { Anderson-Rubin } F \text {-statistic } \\
\text { Hansen } J \text {-statistic }\end{array}$ & - & $\begin{array}{c}\text { infertility } \\
0.0783 \\
{[0.780]}\end{array}$ & $\begin{array}{c}\text { miscarriage } \\
1.050 \\
{[0.306]}\end{array}$ & $\begin{array}{c}\text { overidentified } \\
0.553 \\
{[0.575]} \\
0.657 \\
{[0.418]}\end{array}$ \\
\hline $\begin{array}{l}\text { First stage }-N . \text { children } \\
\text { infertility }\end{array}$ & & $\begin{array}{c}-0.753 * * * \\
(0062)\end{array}$ & & $-0.750 * * *$ \\
\hline miscarriage & & & $\begin{array}{c}-0.476^{* * *} \\
(0.071)\end{array}$ & $\begin{array}{c}-0.469 * * * \\
(0.071)\end{array}$ \\
\hline Angrist-Pischke $F$-statistic instrument(s) & & 145.4 & 45.05 & 96.20 \\
\hline Mother's controls & YES & YES & YES & YES \\
\hline Father's controls & YES & YES & YES & YES \\
\hline Municipality indicators & YES & YES & YES & YES \\
\hline Observations & 18,217 & 18,217 & 18,217 & 18,217 \\
\hline
\end{tabular}

Note. The dependent variable is the total number of children in the household who ever migrated. Mother's controls include year of birth indicators, age and age squared, age at first pregnancy, years of schooling, indicators for mother's chronic illness and being single; father's controls include decade of birth indicators, age and age squared, years of schooling. $P$-values are reported in brackets. $* * *$ and $* * *$ denote statistical significance at 10,5 and 1 percent level, respectively. 
Table 8: Family size effect on having at least a migrant child: Household-level estimates

\begin{tabular}{lcccc}
\hline Variables & $(1)$ & $(2)$ & $(3)$ & $(4)$ \\
\hline & OLS & 2SLS & 2SLS & 2SLS \\
$\begin{array}{l}\text { Second stage } \\
\text { N. children }\end{array}$ & & & & \\
& $0.012^{* * *}$ & 0.001 & -0.016 & -0.003 \\
& $(0.001)$ & $(0.010)$ & $(0.020)$ & $(0.009)$
\end{tabular}

IV:

Anderson-Rubin $F$-statistic

- infertility miscarriage overidentified

Hansen $J$-statistic

$\begin{array}{lll}0.008 & 0.640 & 0.324\end{array}$

$[0.928] \quad[0.424] \quad[0.723]$

0.580

[0.446]

\begin{tabular}{lcccc}
$\begin{array}{l}\text { First stage }-N \text { children } \\
\text { infertility }\end{array}$ & & & \\
& & $(0.753 * * *$ & & $-0.750 * * *$ \\
miscarriage & & & $-0.476 * * *$ & $-0.469 * * *$ \\
& & & $(0.071)$ & $(0.071)$ \\
Angrist-Pischke $F-$ statistic instrument(s) & & 145.42 & 44.95 & 96.17 \\
\hline Mother's controls & YES & YES & YES & YES \\
Father's controls & YES & YES & YES & YES \\
Municipality indicators & YES & YES & YES & YES \\
\hline Observations & 18,217 & 18,217 & 18,217 & 18,217 \\
\hline
\end{tabular}

Note. The dependent variable is a dummy for the household having at least one migrant child. The list of control variables is the same as in Table 7. $P$-values are reported in brackets. ${ }^{*}, * *$ and $* * *$ denote statistical significance at 10,5 and 1 percent level, respectively. 
Table 9: Birth order effects

\begin{tabular}{|c|c|c|}
\hline Variables & (1) & (2) \\
\hline female & $\begin{array}{c}-0.032 * * * \\
(0.006)\end{array}$ & $\begin{array}{c}-0.031 * * * \\
(0.007)\end{array}$ \\
\hline birth order & $\begin{array}{c}-0.019 * * * \\
(0.003)\end{array}$ & \\
\hline birth order $x$ female & $\begin{array}{l}-0.001 \\
(0.001)\end{array}$ & \\
\hline birth order 2 & & $\begin{array}{c}0.002 \\
(0.006)\end{array}$ \\
\hline birth order 3 & & $\begin{array}{c}-0.023 * * * \\
(0.008)\end{array}$ \\
\hline birth order 4 & & $\begin{array}{c}-0.034 * * * \\
(0.011)\end{array}$ \\
\hline birth order 5 & & $\begin{array}{c}-0.070 * * * \\
(0.014)\end{array}$ \\
\hline birth order 6 & & $\begin{array}{c}-0.077 * * * \\
(0.017)\end{array}$ \\
\hline birth order 7 & & $\begin{array}{c}-0.103 * * * \\
(0.020)\end{array}$ \\
\hline birth order 8 & & $\begin{array}{c}-0.140 * * * \\
(0.023)\end{array}$ \\
\hline birth order 9 & & $\begin{array}{c}-0.166^{* * *} * \\
(0.028)\end{array}$ \\
\hline birth order $10+$ & & $\begin{array}{c}-0.188 * * * \\
(0.033)\end{array}$ \\
\hline birth order 2 , female & & $\begin{array}{l}-0.011 \\
(0.009)\end{array}$ \\
\hline birth order 3 , female & & $\begin{array}{c}0.005 \\
(0.010)\end{array}$ \\
\hline birth order 4 , female & & $\begin{array}{l}-0.010 \\
(0.010)\end{array}$ \\
\hline birth order 5 , female & & $\begin{array}{c}0.006 \\
(0.011)\end{array}$ \\
\hline birth order 6 , female & & $\begin{array}{l}-0.018 \\
(0.012)\end{array}$ \\
\hline birth order 7 , female & & $\begin{array}{l}-0.017 \\
(0.015)\end{array}$ \\
\hline birth order 8 , female & & $\begin{array}{c}0.010 \\
(0.018)\end{array}$ \\
\hline birth order 9 , female & & $\begin{array}{c}0.012 \\
(0.024)\end{array}$ \\
\hline birth order $10+$, female & & $\begin{array}{l}-0.022 \\
(0.027)\end{array}$ \\
\hline age & $\begin{array}{c}0.020 * * \\
(0.009)\end{array}$ & $\begin{array}{c}0.021 * * \\
(0.009)\end{array}$ \\
\hline age squared & $\begin{array}{c}0.000 \\
(0.000)\end{array}$ & $\begin{array}{c}0.000 \\
(0.000)\end{array}$ \\
\hline Year of birth indicators & YES & YES \\
\hline Family fixed effects & YES & YES \\
\hline Observations & 26,743 & 26,743 \\
\hline R-squared & 0.050 & 0.053 \\
\hline
\end{tabular}

Note. The dependent variable is a dichotomous indicator of the child's migration status. The model is estimated using OLS. Sibship size is absorbed by family fixed effects. Standard errors clustered at the household level in parentheses. *** and $* * *$ denote statistical significance at 10, 5 and 1 percent level, respectively. 
Table 10: Siblings' composition effect: OLS estimates

\begin{tabular}{lcccc}
\hline Variables & $(1)$ & $(2)$ & $(3)$ & $(4)$ \\
\hline N. older brothers & & & & \\
& $-0.014^{* * *}$ & $-0.014 * * *$ & $-0.017^{* * *}$ & $-0.016^{* * *}$ \\
female & $(0.004)$ & $(0.004)$ & $(0.004)$ & $(0.005)$ \\
& $-0.028^{* * *}$ & $-0.026^{* * *}$ & $-0.022^{* * *}$ & $-0.016^{* * *}$ \\
N. older brothers $\times$ female & $(0.003)$ & $(0.005)$ & $(0.005)$ & $(0.006)$ \\
& & -0.002 & -0.002 & -0.003 \\
Next brother & & $(0.002)$ & $(0.002)$ & $(0.002)$ \\
& & & -0.005 & 0.001 \\
Next brother $\times$ female & & & $(0.004)$ & $(0.004)$ \\
& & & & $-0.012^{* *}$ \\
& & & & $(0.006)$ \\
\hline Age, age squared & YES & YES & YES & YES \\
Birth order fixed effects & YES & YES & YES & YES \\
Year of birth indicators & YES & YES & YES & YES \\
Family fixed effects & YES & YES & YES & YES \\
\hline Observations & 26,743 & 26,743 & 26,743 & 26,743 \\
Number of hid & 10,139 & 10,139 & 10,139 & 10,139 \\
R-squared & 0.053 & 0.053 & 0.053 & 0.053 \\
\hline
\end{tabular}

Note. The dependent variable is a dichotomous indicator of the child's migration status. The model is estimated using OLS. Sibship size is absorbed by family fixed effects. Standard errors clustered at the household level in parentheses. $* * *$ and $* * *$ denote statistical significance at 10, 5 and 1 percent level, respectively. 


\section{A Appendix: Robustness to sample selection}

As described in Section 3, the ENADID provides information on the migration status only for children cohabiting with their parents and for those temporarily absent but still considered as household members. In order to lessen the concerns with the potential selection bias that this may introduce, we make a number of sensitivity checks by changing the composition of the estimation sample.

First, in section A.1 we run a sensitivity check by focusing on the male (sons) subsample, since according to the data boys tend to marry and hence leave their parents' household later compared to girls. Second, in Section A.2 we focus on a sample of individuals aged 15 to 20 as a further robustness check: only few individuals are expected to be out of their origin household in this age group. Moreover, since we are able to recover migration patterns of all individuals who left in the five years prior to the survey, our measure of migration is very precise (very few individuals leave alone before age 15 and can be considered as permanent migrants) at the cost of a smaller sample size. In both cases, the estimation results are very similar to those commented in the main text, although some coefficients are less precisely estimated.

In Section A.3, we carry out a more direct check for sample selection bias. If household partitioning is associated with family size, our estimates would not be representative of the effect of family size on migration for the whole population of children but only for children cohabiting with their parents or who are current household members. To check if this is the case, we estimate a LPM in which the dependent variable is a dichotomous indicator for a child's not being observed in the household ('missing child'). Even for the 'missing children' we can recover some individual level information, namely gender, birth order and age, from the mother's fertility history, so that we can include in the estimated equation exactly the same controls as in the migration equation. First, in column (1) of Table A7, we estimate a reduced form LPM in which we include all the controls of the migration equation except sibship size, but we also include the two excluded instruments used for maternal fertility (miscarriage and infertility conditions). We interpret the test for the joint significance of the coefficients on the two instruments as evidence about the role of family size on a child's choice to permanently leave his/her origin household. Finding statistically 
significant coefficients on the instrumental variables would generate concerns that estimates could be affected by a sample selection bias. We do a similar exercise in column (2) of Table A7 in which we use 2SLS, and test for the significance of family size on the 'missing child' equation. In both cases, we can reject the null hypothesis that family size is a significant driver of a child's probability of being included in the sample used to estimate the decision to migrate abroad.

\section{A.1 Sons}

Table A1: Birth order effects

\begin{tabular}{|c|c|c|}
\hline Variables & (1) & (2) \\
\hline birth order & $\begin{array}{c}-0.019 * * * \\
(0.005)\end{array}$ & \\
\hline birth order 2 & & $\begin{array}{c}0.005 \\
(0.008)\end{array}$ \\
\hline birth order 3 & & $\begin{array}{l}-0.015 \\
(0.013)\end{array}$ \\
\hline birth order 4 & & $\begin{array}{c}-0.030 * \\
(0.018)\end{array}$ \\
\hline birth order 5 & & $\begin{array}{c}-0.061 * * * \\
(0.022)\end{array}$ \\
\hline birth order 6 & & $\begin{array}{c}-0.069 * * \\
(0.028)\end{array}$ \\
\hline birth order 7 & & $\begin{array}{c}-0.109 * * * \\
(0.033)\end{array}$ \\
\hline birth order 8 & & $\begin{array}{c}-0.135 * * * \\
(0.039)\end{array}$ \\
\hline birth order 9 & & $\begin{array}{c}-0.185 * * * \\
(0.046)\end{array}$ \\
\hline birth order $10+$ & & $\begin{array}{c}-0.205^{* * *} * \\
(0.054)\end{array}$ \\
\hline age & $\begin{array}{c}0.052 * * * \\
(0.018)\end{array}$ & $\begin{array}{c}0.051 * * * \\
(0.018)\end{array}$ \\
\hline age squared & $\begin{array}{l}-0.001 \\
(0.000)\end{array}$ & $\begin{array}{l}-0.001 \\
(0.000)\end{array}$ \\
\hline Year of birth indicators & YES & YES \\
\hline Family fixed effects & YES & YES \\
\hline Observations & 14,777 & 14,777 \\
\hline $\mathrm{R}$-squared & 0.059 & 0.063 \\
\hline
\end{tabular}

Note. The dependent variable is a dichotomous indicator of the child's migration status. The model is estimated using OLS. Sibship size is absorbed by family fixed effects. Standard errors clustered at the household level in parentheses. *** and $* * *$ denote statistical significance at 10,5 and 1 percent level, respectively. 
Table A2: Sibship size effect: WLS and IV estimates

\begin{tabular}{|c|c|c|c|c|}
\hline Variables & $\begin{array}{c}(1) \\
\text { WLS }\end{array}$ & $\begin{array}{c}(2) \\
2 \mathrm{SLS}\end{array}$ & $\begin{array}{c}(3) \\
2 \mathrm{SLS}\end{array}$ & $\begin{array}{c}(4) \\
2 S L S\end{array}$ \\
\hline N. siblings & $\begin{array}{l}0.012 * * * \\
(0.001)\end{array}$ & $\begin{array}{c}0.004 \\
(0.019)\end{array}$ & $\begin{array}{l}-0.051 \\
(0.036)\end{array}$ & $\begin{array}{l}-0.016 \\
(0.017)\end{array}$ \\
\hline $\begin{array}{l}\text { IV: } \\
\text { Anderson-Rubin } F \text {-statistic } \\
\text { Hansen } J \text {-statistic }\end{array}$ & - & $\begin{array}{l}\text { infertility } \\
0.0355 \\
{[0.850]}\end{array}$ & $\begin{array}{c}\text { miscarriage } \\
2.567 \\
{[0.109]}\end{array}$ & $\begin{array}{c}\text { overidentified } \\
1.315 \\
{[0.268]} \\
2.175 \\
{[0.140]}\end{array}$ \\
\hline $\begin{array}{l}\text { First stage }-N \text {. siblings } \\
\text { infertility }\end{array}$ & & $\begin{array}{c}-0.549 * * * \\
(0.110)\end{array}$ & & $\begin{array}{c}-0.547 * * * \\
(0.109)\end{array}$ \\
\hline miscarriage & & & $\begin{array}{c}-0.441 * * * \\
(0.117)\end{array}$ & $\begin{array}{c}-0.438 * * * \\
(0.117)\end{array}$ \\
\hline Angrist-Pischke $F$-statistic instrument(s) & & 25.13 & 14.19 & 20.38 \\
\hline Individual's controls & YES & YES & YES & YES \\
\hline Mother's controls & YES & YES & YES & YES \\
\hline Father's controls & YES & YES & YES & YES \\
\hline Municipality indicators & YES & YES & YES & YES \\
\hline $\begin{array}{l}\text { Observations } \\
\text { R-squared }\end{array}$ & $\begin{array}{c}14,777 \\
0.242\end{array}$ & 14,777 & 14,777 & 14,777 \\
\hline
\end{tabular}

Note. The dependent variable is netted migration (see Section 4). Observations are weighted by the inverse of the standard error of netted migration. Individual's controls include year of birth indicators, age, age squared; mother's controls include year of birth indicators, age and age squared, age at first pregnancy, years of schooling, indicators for mother's chronic illness and being single; father's controls include decade of birth indicators, age and age squared, years of schooling. Standard errors clustered at the household level in parentheses. $P$-values are reported in brackets. $* * *$ and $* * *$ denote statistical significance at 10,5 and 1 percent level, respectively. 


\section{A.2 Age group 15-20}

Table A3: Birth order effects

\begin{tabular}{|c|c|c|c|c|}
\hline Variables & (1) & (2) & (3) & (4) \\
\hline female & $\begin{array}{c}-0.025 * * * \\
(0.003)\end{array}$ & $\begin{array}{c}-0.025^{* * * *} \\
(0.003)\end{array}$ & $\begin{array}{c}-0.021 * * * \\
(0.006)\end{array}$ & $\begin{array}{c}-0.020 * * \\
(0.008)\end{array}$ \\
\hline birth order & $\begin{array}{l}-0.003 \\
(0.004)\end{array}$ & & $\begin{array}{l}-0.003 \\
(0.004)\end{array}$ & \\
\hline birth order $\times \mathrm{f}$ female & & & $\begin{array}{c}-0.001 \\
(0.001)\end{array}$ & \\
\hline birth order 2 & & $\begin{array}{c}0.008 \\
(0.006)\end{array}$ & & $\begin{array}{c}0.011 \\
(0.007)\end{array}$ \\
\hline birth order 3 & & $\begin{array}{c}0.005 \\
(0.010)\end{array}$ & & $\begin{array}{c}0.009 \\
(0.011)\end{array}$ \\
\hline birth order 4 & & $\begin{array}{c}0.004 \\
(0.014)\end{array}$ & & $\begin{array}{c}0.003 \\
(0.015)\end{array}$ \\
\hline birth order 5 & & $\begin{array}{l}-0.004 \\
(0.018)\end{array}$ & & $\begin{array}{l}-0.007 \\
(0.019)\end{array}$ \\
\hline birth order 6 & & $\begin{array}{l}-0.009 \\
(0.022)\end{array}$ & & $\begin{array}{l}-0.007 \\
(0.023)\end{array}$ \\
\hline birth order 7 & & $\begin{array}{l}-0.015 \\
(0.027)\end{array}$ & & $\begin{array}{l}-0.003 \\
(0.028)\end{array}$ \\
\hline birth order 8 & & $\begin{array}{l}-0.036 \\
(0.031)\end{array}$ & & $\begin{array}{l}-0.036 \\
(0.032)\end{array}$ \\
\hline birth order 9 & & $\begin{array}{c}-0.047 \\
(0.036)\end{array}$ & & $\begin{array}{c}-0.039 \\
(0.038)\end{array}$ \\
\hline birth order $10+$ & & $\begin{array}{c}-0.084 * * \\
(0.042)\end{array}$ & & $\begin{array}{l}-0.078^{*} \\
(0.044)\end{array}$ \\
\hline birth order 2 , female & & & & $\begin{array}{c}-0.008 \\
(0.010)\end{array}$ \\
\hline birth order 3 , female & & & & $\begin{array}{c}-0.008 \\
(0.011)\end{array}$ \\
\hline birth order 4 , female & & & & $\begin{array}{c}0.002 \\
(0.011)\end{array}$ \\
\hline birth order 5 , female & & & & $\begin{array}{c}0.005 \\
(0.012)\end{array}$ \\
\hline birth order 6 , female & & & & $\begin{array}{l}-0.005 \\
(0.014)\end{array}$ \\
\hline birth order 7 , female & & & & $\begin{array}{c}-0.027 * \\
(0.015)\end{array}$ \\
\hline birth order 8 , female & & & & $\begin{array}{c}0.001 \\
(0.018)\end{array}$ \\
\hline birth order 9 , female & & & & $\begin{array}{c}-0.016 \\
(0.023)\end{array}$ \\
\hline birth order $10+$, female & & & & $\begin{array}{c}-0.012 \\
(0.025)\end{array}$ \\
\hline age & $\begin{array}{c}0.007 \\
(0.007)\end{array}$ & $\begin{array}{c}0.007 \\
(0.007)\end{array}$ & $\begin{array}{c}0.007 \\
(0.007)\end{array}$ & $\begin{array}{c}0.007 \\
(0.007)\end{array}$ \\
\hline age squared & $\begin{array}{c}0.000 \\
(0.000)\end{array}$ & $\begin{array}{c}0.000 \\
(0.000)\end{array}$ & $\begin{array}{c}0.000 \\
(0.000)\end{array}$ & $\begin{array}{c}0.000 \\
(0.000)\end{array}$ \\
\hline Year of birth indicators & YES & YES & YES & YES \\
\hline Family fixed effects & YES & YES & YES & YES \\
\hline Observations & 18,707 & 18,707 & 18,707 & 18,707 \\
\hline R-squared & 0.050 & 0.052 & 0.051 & 0.053 \\
\hline
\end{tabular}

Note. The dependent variable is a dichotomous indicator of the child's migration status. The model is estimated using OLS. Sibship size is absorbed by family fixed effects. Standard errors clustered at the household level in parentheses. $* * *$ and $* * *$ denote statistical significance at 10,5 and 1 percent level, respectively. 
Table A4: Sibship size effect: WLS estimates

\begin{tabular}{lcc}
\hline Variables & $(1)$ & $(2)$ \\
\hline N. siblings & & \\
& $\left(0.005^{* * *}\right.$ & $0.006^{* * *}$ \\
N. siblings $\times$ female & & $(0.001)$ \\
& & $-0.004^{* * *}$ \\
female & $-0.024^{* * *}$ & $-0.023^{* * *}$ \\
& $(0.003)$ & $(0.002)$ \\
& & \\
Individual's controls & YES & YES \\
Mother's controls & YES & YES \\
Father's controls & YES & YES \\
Municipality indicators & YES & YES \\
\hline Observations & 18,707 & 18,707 \\
R-squared & 0.177 & 0.178 \\
\hline
\end{tabular}

Note. The dependent variable is netted migration (see Section 4). The model is estimated using Weighted Least Squares (weights are the inverse of the standard errors of netted migration). Individual's controls include year of birth indicators, age, age squared; mother's controls include year of birth indicators, age and age squared, age at first pregnancy, years of schooling, indicators for mother's chronic illness and being single; father's controls include decade of birth indicators, age and age squared, years of schooling. Standard errors clustered at the household level in parentheses. *,** and *** denote statistical significance at 10, 5 and 1 percent level, respectively. 
Table A5: Sibliship size effect: 2SLS estimates

\begin{tabular}{|c|c|c|c|}
\hline Variables & (1) & (2) & (3) \\
\hline \multicolumn{4}{|l|}{ Second stage } \\
\hline N. siblings & $\begin{array}{c}0.005 \\
(0.014)\end{array}$ & $\begin{array}{l}-0.012 \\
(0.020)\end{array}$ & $\begin{array}{l}-0.002 \\
(0.011)\end{array}$ \\
\hline female & $\begin{array}{c}-0.024 * * * \\
(0.003)\end{array}$ & $\begin{array}{c}-0.025 * * * \\
(0.003)\end{array}$ & $\begin{array}{c}-0.025 * * * \\
(0.003)\end{array}$ \\
\hline IV: & infertility & miscarriage & overidentified \\
\hline Anderson-Rubin $F$-statistic & $\begin{array}{c}0.146 \\
{[0.702]}\end{array}$ & $\begin{array}{c}0.377 \\
{[0.539]}\end{array}$ & $\begin{array}{c}0.257 \\
{[0.773]}\end{array}$ \\
\hline Hansen $J$-statistic & & & $\begin{array}{c}0.515 \\
{[0.473]}\end{array}$ \\
\hline First stage $-N$. siblings & & & \\
\hline infertility & $\begin{array}{c}-0.455^{* * *} * \\
(0.102)\end{array}$ & & $\begin{array}{c}-0.452 * * * \\
(0.102)\end{array}$ \\
\hline miscarriage & & $\begin{array}{c}-0.412 * * * \\
(0.105)\end{array}$ & $\begin{array}{c}-0.408 * * * \\
(0.105)\end{array}$ \\
\hline Angrist-Pischke $F$-statistic instrument(s) & 19.78 & 15.43 & 17.82 \\
\hline Individual's controls & YES & YES & YES \\
\hline Mother's controls & YES & YES & YES \\
\hline Father's controls & YES & YES & YES \\
\hline Municipality indicators & YES & YES & YES \\
\hline Observations & 18,707 & 18,707 & 18,707 \\
\hline
\end{tabular}

Note. The dependent variable is netted migration (see Section 4). Observations are weighted by the inverse of the standard error of netted migration. Individual's controls include year of birth indicators, age, age squared; mother's controls include year of birth indicators, age and age squared, age at first pregnancy, years of schooling, indicators for mother's chronic illness and being single; father's controls include decade of birth indicators, age and age squared, years of schooling. Standard errors clustered at the household level in parentheses. $P$-values are reported in brackets. ${ }^{* * *}$ and $* * *$ denote statistical significance at 10,5 and 1 percent level, respectively. 
Table A6: Child gender and sibship size effect: 2SLS estimates

\begin{tabular}{|c|c|c|c|}
\hline Variables & (1) & (2) & (3) \\
\hline \multicolumn{4}{|l|}{ Second stage } \\
\hline N. siblings & $\begin{array}{c}0.011 \\
(0.018)\end{array}$ & $\begin{array}{l}-0.052 \\
(0.047)\end{array}$ & $\begin{array}{c}0.000 \\
(0.014)\end{array}$ \\
\hline N. siblings $\times$ female & $\begin{array}{l}-0.014 \\
(0.014)\end{array}$ & $\begin{array}{c}0.088 \\
(0.074)\end{array}$ & $\begin{array}{l}-0.003 \\
(0.014)\end{array}$ \\
\hline female & $\begin{array}{c}-0.020 * * * \\
(0.005)\end{array}$ & $\begin{array}{c}-0.053^{* *} \\
(0.024)\end{array}$ & $\begin{array}{c}-0.024 * * * \\
(0.005)\end{array}$ \\
\hline IV: & infertility & miscarriage & overidentified \\
\hline Anderson-Rubin $F$-statistic & $\begin{array}{c}0.499 \\
{[0.607]}\end{array}$ & $\begin{array}{c}1.282 \\
{[0.278]}\end{array}$ & $\begin{array}{c}0.873 \\
{[0.479]}\end{array}$ \\
\hline Hansen $J$-statistic & & & $\begin{array}{c}3.235 \\
{[0.198]}\end{array}$ \\
\hline First stage $-N$. siblings & & & \\
\hline infertility & $\begin{array}{c}-0.486 * * * \\
(0.123)\end{array}$ & & $\begin{array}{l}-0.483^{* * *} \\
(0.123)\end{array}$ \\
\hline infertility $\times$ female & $\begin{array}{c}0.069 \\
(0.139)\end{array}$ & & $\begin{array}{c}0.071 \\
(0.139)\end{array}$ \\
\hline miscarriage & & $\begin{array}{c}-0.397 * * * \\
(0.129)\end{array}$ & $\begin{array}{c}-0.394 * * * \\
(0.129)\end{array}$ \\
\hline miscarriage $\times$ female & & $\begin{array}{l}-0.034 \\
(0.127)\end{array}$ & $\begin{array}{l}-0.031 \\
(0.127)\end{array}$ \\
\hline Angrist-Pischke $F$-statistic instrument(s) & 9.897 & 8.289 & 9.13 \\
\hline $\begin{array}{l}\text { First stage }-N \text {. siblings } \times \text { female } \\
\text { infertility }\end{array}$ & $\begin{array}{c}0.119 * * * \\
(0.041)\end{array}$ & & $\begin{array}{l}0.120 * * * \\
(0.041)\end{array}$ \\
\hline infertility $\times$ female & $\begin{array}{c}-0.691 * * * \\
(0.139)\end{array}$ & & $\begin{array}{c}-0.688 * * * \\
(0.139)\end{array}$ \\
\hline miscarriage & & $\begin{array}{l}-0.056 \\
(0.049)\end{array}$ & $\begin{array}{l}-0.057 \\
(0.049)\end{array}$ \\
\hline miscarriage $\times$ female & & $\begin{array}{l}-0.289 * * \\
(0.137)\end{array}$ & $\begin{array}{l}-0.281 * * \\
(0.136)\end{array}$ \\
\hline Angrist-Pischke $F$-statistic instrument(s) & 12.93 & 5.392 & 8.97 \\
\hline Individual's controls & YES & YES & YES \\
\hline Mother's controls & YES & YES & YES \\
\hline Father's controls & YES & YES & YES \\
\hline Municipality indicators & YES & YES & YES \\
\hline Observations & 18,707 & 18,707 & 18,707 \\
\hline
\end{tabular}

Note. The dependent variable is netted migration (see Section 4). Observations are weighted by the inverse of the standard error of netted migration. Individual's controls include year of birth indicators, age, age squared; mother's controls include year of birth indicators, age and age squared, age at first pregnancy, years of schooling, indicators for mother's chronic illness and being single; father's controls include decade of birth indicators, age and age squared, years of schooling. Standard errors clustered at the household level in parentheses. $P$-values are reported in brackets. $*^{* *}$ and $* * *$ denote statistical significance at 10, 5 and 1 percent level, respectively. 


\section{A.3 Sample Selection Bias}

Table A7: The effect of family size on being a 'missing child'

\begin{tabular}{lcc}
\hline Variables & $(1)$ & $(2)$ \\
& OLS & 2SLS \\
\hline & & \\
infertility & -0.013 & \\
& $(0.010)$ & \\
miscarriage & 0.002 & \\
& $(0.011)$ & \\
N. siblings & & 0.015 \\
& & $(0.015)$ \\
$F-$ statistic instruments & $(a)$ \\
IV: & 0.838 & \\
Anderson-Rubin $F-$ statistic & - & overidentified \\
& & 0.838 \\
Hansen $J-$ statistic & & {$[0.433]$} \\
& & 0.875 \\
& & {$[0.350]$} \\
Individual's controls & YES & YES \\
Mother's controls & YES & YES S \\
Father's controls & YES & YES \\
Municipality indicators & YES & YES \\
\hline Observations & 34,852 & 34,852 \\
\hline
\end{tabular}

Note. The dependent variable is a dichotomous indicator of the child's not being observed in the household of origin ('missing child'). The model is estimated using OLS in column (1) and two-stage least squares in column (2). Standard errors clustered at the household level in parentheses. ${ }^{(a)} F-$ statistic for the joint test that infertility and miscarriage are zero in the 'missing child' equation. *** and *** denote statistical significance at 10,5 and 1 percent level, respectively.

\section{B Appendix: Poverty and identification threats}

In developing countries women's infertility conditions may partly depend on material poverty, which affects women's health. Failing to control for economic conditions may represent a threat to our IV estimates because poverty is also likely to affect children's migration status. In the baseline estimates of Section 5.2 we took into account this potential threat by including some strong correlates of individual or household poverty, such as parents' educational levels, age and municipality fixed effects. In this Section, we run supplementary checks by estimating models including municipality by (ENADID) wave fixed effects, municipality by parent's education fixed effects (years of education of the most educated parent, either the mother of the father, are interacted with municipality indicators) and an index of household wealth (constructed by using Principal Component Analysis and information on household's 
type of floor and toilette, and access to water and electricity). Results are reported in columns (1), (2) and (3) of Table B1, respectively. They also serve as checks of potential concerns related to the miscarriage at first pregnancy instrument, which may be affected by women's living standards as well. The results confirm the robustness of our estimates of family size effects to including alternative proxies of household poverty.

Table B1: Robustness of IV estimates to various proxies of poverty

\begin{tabular}{|c|c|c|c|}
\hline Variables & (1) & (2) & (3) \\
\hline \multicolumn{4}{|l|}{ Second stage } \\
\hline N. siblings & $\begin{array}{l}-0.009 \\
(0.011)\end{array}$ & $\begin{array}{l}-0.009 \\
(0.011)\end{array}$ & $\begin{array}{l}-0.006 \\
(0.014)\end{array}$ \\
\hline IV: & overidentified & overidentified & overidentified \\
\hline Anderson-Rubin $F$-statistic & $\begin{array}{c}0.666 \\
{[0.514]}\end{array}$ & $\begin{array}{c}0.603 \\
{[0.547]}\end{array}$ & $\begin{array}{c}0.397 \\
{[0.672]}\end{array}$ \\
\hline Hansen $J$-statistic & $\begin{array}{c}0.827 \\
{[0.363]}\end{array}$ & $\begin{array}{c}0.822 \\
{[0.365]}\end{array}$ & $\begin{array}{c}0.745 \\
{[0.388]}\end{array}$ \\
\hline First stage $-N$. siblings & & & \\
\hline infertility & $\begin{array}{c}-0.552 * * * \\
(0 . .092)\end{array}$ & $\begin{array}{c}-0.546 * * * \\
(0.089)\end{array}$ & $\begin{array}{c}-0.455^{* * *} * \\
(0.095)\end{array}$ \\
\hline miscarriage & $\begin{array}{c}-0.470 * * * \\
(0.096)\end{array}$ & $\begin{array}{c}-0.439 * * * \\
(0.095)\end{array}$ & $\begin{array}{c}-0.384 * * * \\
(0.095)\end{array}$ \\
\hline Angrist-Pischke $F$-statistic instrument(s) & 30.83 & 30.05 & 19.73 \\
\hline Municipality $\times$ Wave indicators & YES & $\mathrm{NO}$ & $\mathrm{NO}$ \\
\hline Municipality $\times$ parents' education indicators & NO & YES & $\mathrm{NO}$ \\
\hline Household wealth indicator & NO & NO & YES \\
\hline Individual's controls & YES & YES & YES \\
\hline Mother's controls & YES & YES & YES \\
\hline Father's controls & YES & YES & YES \\
\hline Municipality indicators & YES & YES & YES \\
\hline Observations & 26,743 & 26,743 & 26,743 \\
\hline
\end{tabular}

Note. The dependent variable is netted migration (see Section 4). Observations are weighted by the inverse of the standard error of netted migration. Individual's controls include year of birth indicators, age, age squared; mother's controls include year of birth indicators, age and age squared, age at first pregnancy, years of schooling, indicators for mother's chronic illness and being single; father's controls include decade of birth indicators, age and age squared, years of schooling. Standard errors clustered at the household level in parentheses. $P$-values are reported in brackets. $* * *$ and $* * *$ denote statistical significance at 10,5 and 1 percent level, respectively. 
C Appendix: Sibship size including deceased children 
Table C1: Birth order effects

\begin{tabular}{|c|c|c|c|c|}
\hline Variables & (1) & (2) & (3) & (4) \\
\hline female & $\begin{array}{c}-0.035 * * * \\
(0.003)\end{array}$ & $\begin{array}{c}-0.035 * * * \\
(0.003)\end{array}$ & $\begin{array}{c}-0.031 * * * \\
(0.005)\end{array}$ & $\begin{array}{c}-0.031 * * * \\
(0.007)\end{array}$ \\
\hline birth order & $\begin{array}{c}-0.017 * * * \\
(0.003)\end{array}$ & & $\begin{array}{c}-0.016 * * * \\
(0.003)\end{array}$ & \\
\hline birth order $\times$ female & & & $\begin{array}{c}-0.001 \\
(0.001)\end{array}$ & \\
\hline birth order 2 & & $\begin{array}{c}-0.003 \\
(0.005)\end{array}$ & & $\begin{array}{c}0.001 \\
(0.006)\end{array}$ \\
\hline birth order 3 & & $\begin{array}{c}-0.013 * \\
(0.007)\end{array}$ & & $\begin{array}{c}-0.016 * \\
(0.008)\end{array}$ \\
\hline birth order 4 & & $\begin{array}{c}-0.031^{* * *} \\
(0.010)\end{array}$ & & $\begin{array}{c}-0.030 * * * \\
(0.011)\end{array}$ \\
\hline birth order 5 & & $\begin{array}{c}-0.057 * * * \\
(0.012)\end{array}$ & & $\begin{array}{c}-0.055^{* * *} * \\
(0.013)\end{array}$ \\
\hline birth order 6 & & $\begin{array}{c}-0.076^{* * *} \\
(0.015)\end{array}$ & & $\begin{array}{c}-0.070 * * * \\
(0.016)\end{array}$ \\
\hline birth order 7 & & $\begin{array}{c}-0.091 * * * \\
(0.017)\end{array}$ & & $\begin{array}{c}-0.081 * * * \\
(0.018)\end{array}$ \\
\hline birth order 8 & & $\begin{array}{c}-0.120 * * * \\
(0.020)\end{array}$ & & $\begin{array}{c}-0.116^{* * *} * \\
(0.022)\end{array}$ \\
\hline birth order 9 & & $\begin{array}{c}-0.133 * * * \\
(0.023)\end{array}$ & & $\begin{array}{c}-0.143 * * * \\
(0.025)\end{array}$ \\
\hline birth order $10+$ & & $\begin{array}{c}-0.164 * * * \\
(0.027)\end{array}$ & & $\begin{array}{c}-0.158 * * * \\
(0.029)\end{array}$ \\
\hline birth order 2 , female & & & & $\begin{array}{c}-0.010 \\
(0.010)\end{array}$ \\
\hline birth order 3 , female & & & & $\begin{array}{c}0.006 \\
(0.010)\end{array}$ \\
\hline birth order 4 , female & & & & $\begin{array}{l}-0.002 \\
(0.011)\end{array}$ \\
\hline birth order 5 , female & & & & $\begin{array}{c}-0.003 \\
(0.011)\end{array}$ \\
\hline birth order6, female & & & & $\begin{array}{l}-0.013 \\
(0.012)\end{array}$ \\
\hline birth order 7 , female & & & & $\begin{array}{l}-0.023 * \\
(0.014)\end{array}$ \\
\hline birth order 8 , female & & & & $\begin{array}{c}-0.007 \\
(0.016)\end{array}$ \\
\hline birth order 9 , female & & & & $\begin{array}{c}0.022 \\
(0.019)\end{array}$ \\
\hline birth order $10+$, female & & & & $\begin{array}{c}-0.012 \\
(0.019)\end{array}$ \\
\hline age & $\begin{array}{c}0.022 * * \\
(0.009)\end{array}$ & $\begin{array}{c}0.022 * * \\
(0.009)\end{array}$ & $\begin{array}{c}0.022 * * \\
(0.009)\end{array}$ & $\begin{array}{c}0.022 * * \\
(0.009)\end{array}$ \\
\hline age squared & $\begin{array}{c}0.000 \\
(0.000)\end{array}$ & $\begin{array}{l}-0.000 \\
(0.000)\end{array}$ & $\begin{array}{c}0.000 \\
(0.000)\end{array}$ & $\begin{array}{l}-0.000 \\
(0.000)\end{array}$ \\
\hline Year of birth indicators & YES & YES & YES & YES \\
\hline Family fixed effects & YES & YES & YES & YES \\
\hline Observations & 26,743 & 26,743 & 26,743 & 26,743 \\
\hline Number of households & 10,139 & 10,139 & 10,139 & 10,139 \\
\hline R-squared & 0.050 & 0.052 & 0.050 & 0.052 \\
\hline
\end{tabular}

Note. The dependent variable is a dichotomous indicator of the child's migration status. The model is estimated using OLS. Sibship size is absorbed by family fixed effects. Standard errors clustered at the household level in parentheses. $*$,** and $* * *$ denote statistical significance at 10, 5 and 1 percent level, respectively. 
Table C2: Sibship size effect: WLS estimates

\begin{tabular}{lcc}
\hline Variables & $(1)$ & $(2))$ \\
\hline & & \\
N. siblings & $0.010^{* * *}$ & $0.013^{* * *}$ \\
& $(0.001)$ & $(0.001)$ \\
N. siblings $\times$ female & & $-0.007 * * *$ \\
& & $(0.001)$ \\
female & $-0.032^{* * *}$ & $-0.030^{* * *}$ \\
& $(0.003)$ & $(0.003)$ \\
& & \\
& & \\
Individual's controls & YES & YES \\
Mother's controls & YES & YES \\
Father's controls & YES & YES \\
Municipality indicators & YES & \\
Weighted & YES & YES \\
\hline Observations & 26,743 & 26,743 \\
R-squared & 0.204 & 0.206 \\
\hline
\end{tabular}

Note. The dependent variable is netted migration (see Section 4). The model is estimated using Weighted Least Squares (the weights are the inverse of the standard errors of netted migration). Individual's controls include year of birth indicators, age, age squared; mother's controls include year of birth indicators, age and age squared, age at first pregnancy, years of schooling, indicators for mother's chronic illness and being single; father's controls include decade of birth indicators, age and age squared, years of schooling. Standard errors clustered at the household level in parentheses. $* * *$ and $* * *$ denote statistical significance at 10, 5 and 1 percent level, respectively. 
Table C3: Sibship size effect: 2SLS estimates

\begin{tabular}{|c|c|c|c|}
\hline Variables & (1) & (2) & (3) \\
\hline \multicolumn{4}{|l|}{ Second stage } \\
\hline N. siblings & $\begin{array}{c}0.002 \\
(0.014)\end{array}$ & $\begin{array}{l}-0.015 \\
(0.024)\end{array}$ & $\begin{array}{l}-0.005 \\
(0.013)\end{array}$ \\
\hline female & $\begin{array}{c}-0.032 * * * \\
(0.003)\end{array}$ & $\begin{array}{c}-0.033 * * * \\
(0.003)\end{array}$ & $\begin{array}{c}-0.032 * * * \\
(0.003)\end{array}$ \\
\hline IV: & infertility & miscarriage & overidentified \\
\hline Anderson-Rubin $F$-statistic & $\begin{array}{l}0.0229 \\
{[0.880]}\end{array}$ & $\begin{array}{c}0.433 \\
{[0.510]}\end{array}$ & $\begin{array}{c}0.232 \\
{[0.793]}\end{array}$ \\
\hline Hansen $J$-statistic & & & $\begin{array}{c}0.419 \\
{[0.517]}\end{array}$ \\
\hline First stage $-N$. siblings & & & \\
\hline infertility & $\begin{array}{c}-0.475^{* * *} * \\
(0.095)\end{array}$ & & $\begin{array}{c}-0.472 * * * \\
(0.095)\end{array}$ \\
\hline miscarriage & & $\begin{array}{c}-0.411 * * * \\
(0.10)\end{array}$ & $\begin{array}{c}-0.407 * * * \\
(0.10)\end{array}$ \\
\hline Angrist-Pischke $F$-statistic instrument(s) & 25.01 & 17.78 & 21.70 \\
\hline Individual's controls & YES & YES & YES \\
\hline Mother's controls & YES & YES & YES \\
\hline Father's controls & YES & YES & YES \\
\hline Municipality indicators & YES & YES & YES \\
\hline Observations & 26,743 & 26,743 & 26,743 \\
\hline
\end{tabular}

Note. The dependent variable is netted migration (see Section 4). Observations are weighted by the inverse of the standard error of netted migration. Individual's controls include year of birth indicators, age, age squared; mother's controls include year of birth indicators, age and age squared, age at first pregnancy, years of schooling, indicators for mother's chronic illness and being single; father's controls include decade of birth indicators, age and age squared, years of schooling. Standard errors clustered at the household level in parentheses. $P$-values are reported in brackets. ${ }^{* * *}$ and $* * *$ denote statistical significance at 10,5 and 1 percent level, respectively. 
Table C4: Child gender and sibship size effect: 2SLS estimates

\begin{tabular}{|c|c|c|c|}
\hline Variables & (1) & (2) & (3) \\
\hline \multicolumn{4}{|l|}{ Second stage } \\
\hline N. siblings & $\begin{array}{c}0.002 \\
(0.016)\end{array}$ & $\begin{array}{l}-0.065 \\
(0.057)\end{array}$ & $\begin{array}{l}-0.006 \\
(0.015)\end{array}$ \\
\hline N. siblings $\times$ female & $\begin{array}{l}-0.001 \\
(0.013)\end{array}$ & $\begin{array}{c}0.105 \\
(0.084)\end{array}$ & $\begin{array}{c}0.007 \\
(0.013)\end{array}$ \\
\hline female & $\begin{array}{c}-0.032 * * * \\
(0.004)\end{array}$ & $\begin{array}{c}-0.059 * * * \\
(0.022)\end{array}$ & $\begin{array}{c}-0.034 * * * \\
(0.004)\end{array}$ \\
\hline IV: & infertility & miscarriage & overidentified \\
\hline Anderson-Rubin $F$-statistic & $\begin{array}{l}0.0115 \\
{[0.989]}\end{array}$ & $\begin{array}{c}1.577 \\
{[0.207]}\end{array}$ & $\begin{array}{c}0.797 \\
{[0.527]}\end{array}$ \\
\hline Hansen $J$-statistic & & & $\begin{array}{l}2.925 \\
{[0.232]}\end{array}$ \\
\hline First stage $-N$. siblings & & & \\
\hline infertility & $\begin{array}{l}-0.557 * * * \\
(0.107)\end{array}$ & & $\begin{array}{l}-0.555^{* * *} \\
(0.107)\end{array}$ \\
\hline infertility $\times$ female & $\begin{array}{c}0.168 \\
(0.115)\end{array}$ & & $\begin{array}{l}0.190 * \\
(0.114)\end{array}$ \\
\hline miscarriage & & $\begin{array}{l}-0.390 * * * \\
(0.113)\end{array}$ & $\begin{array}{c}-0.387 * * * \\
(0.113)\end{array}$ \\
\hline miscarriage $\times$ female & & $\begin{array}{c}0.046 \\
(0.106)\end{array}$ & $\begin{array}{l}-0.046 \\
(0.102)\end{array}$ \\
\hline Angrist-Pischke $F$-statistic instrument(s) & 31.59 & 5.74 & 19.49 \\
\hline $\begin{array}{l}\text { First stage }-N \text {. siblings } \times \text { female } \\
\text { infertility }\end{array}$ & $\begin{array}{c}0.135 * * * \\
(0.039)\end{array}$ & & $\begin{array}{l}0.136 * * * \\
(0.038)\end{array}$ \\
\hline infertility $\times$ female & $\begin{array}{c}-0.689 * * * \\
(0.134)\end{array}$ & & $\begin{array}{c}-0.686 * * * \\
(0.134)\end{array}$ \\
\hline miscarriage & & $\begin{array}{l}-0.066 \\
(0.044)\end{array}$ & $\begin{array}{l}-0.068 \\
(0.044)\end{array}$ \\
\hline miscarriage $\times$ female & & $\begin{array}{l}-0.287 * * \\
(0.131)\end{array}$ & $\begin{array}{l}-0.280 * * \\
(0.130)\end{array}$ \\
\hline Angrist-Pischke $F$-statistic instrument(s) & 40.51 & 4.55 & 17.22 \\
\hline Individual's controls & YES & YES & YES \\
\hline Mother's controls & YES & YES & YES \\
\hline Father's controls & YES & YES & YES \\
\hline Municipality indicators & YES & YES & YES \\
\hline Observations & 26,743 & 26,743 & 26,743 \\
\hline
\end{tabular}

Note. The dependent variable is netted migration (see Section 4). Observations are weighted by the inverse of the standard error of netted migration. Individual's controls include year of birth indicators, age, age squared; mother's controls include year of birth indicators, age and age squared, age at first pregnancy, years of schooling, indicators for mother's chronic illness and being single; father's controls include decade of birth indicators, age and age squared, years of schooling. Standard errors clustered at the household level in parentheses. $P$-values are reported in brackets. ${ }^{(a)}$ The number of siblings is demeaned before taking the interaction. $*, * *$ and $* * *$ denote statistical significance at 10,5 and 1 percent level, respectively. 